\author{
Maksym Potapenko \\ (1) https://orcid.org/0000-0002-0000-8892 \\ Niżyński Uniwersytet Państwowy im. Mikołaja Gogola
}

\title{
ORMIANIE MOHYLOWA PODOLSKIEGO POD KONIEC XVIII I W POŁOWIE XIX WIEKU (NA PODSTAWIE POMIARÓW STATYSTYCZNYCH LUDNOŚCI)
}

\begin{abstract}
Abstrakt: W artykule przeprowadzono analizę pięciu źródeł statystycznych, które dokumentują społeczny i demograficzny charakter gminy ormiańskiej Mohylowa Podolskiego od końca XVIII do połowy XIX wieku. Są to: inwentarz miasta z 1772 roku i tzw. rewizje, przeprowadzane na polecenie władz rosyjskich w latach 1795 , 1811, 1834 i 1850. W rezultacie udało się ustalić nazwiska co najmniej 600 Ormian mohylowskich z 70 rodzin. Potwierdzona też została teza o tym, że Ormianie w tym mieście stanowili odrębną i uprzywilejowaną grupę społeczną, która - jak to już sądził Wartan Grigorian - zanikała, głównie ze względu na niekorzystną dla niej sytuację ekonomiczną po włączeniu Podola w skład Rosji.
\end{abstract}

Słowa kluczowe: Ormianie, Mohylów Podolski

Historia wspólnoty ormiańskiej Mohylowa Podolskiego pozostaje niedostatecznie zbadana. Ze względu na brak źródeł wprowadzonych do obiegu naukowego niektóre aspekty budzą dyskusje bądź nawet są zupełnie nieznane. Otwartymi pozostają pytania o liczebność Ormian w mieście i specyfikę ich zawodów. Ponadto prawie nic nie wiadomo o tym, jak zmieniła się sytuacja ich wspólnoty po drugim rozbiorze Polski w 1793 roku i wejściu Podola w skład Rosji. Rzetelne i kompletne informacje posiadamy jedynie o życiu religijnym Ormian Mohylowa Podolskiego w czasach rosyjskiego panowania, w szczególności dotyczące funkcjonowania ormiańskokatolickiej diecezji mohylowskiej ${ }^{1}$.

${ }^{1}$ В. Григорян, История армянских колоний Украины и Польши (армяне Подолии), Ереван 1980, s. 170-174; K. Stopka, A. A. Zięba, Ormiańska Polska, Warszawa 2018, 
$\mathrm{Na}$ te oraz inne pytania rzucają światło odnalezione w ciągu ostatnich dwóch lat dane statystyczne. Chodzi o inwentarz miasta z $1772 \mathrm{roku}^{2}$, a także materiały V (1795) $)^{3}$, VI $(1811)^{4}$, VIII $(1834)^{5}$ i IX $(1850)^{6}$ rewizji rosyjskich. Źródła te pozwalają odtworzyć ważne społeczne i demograficzne cechy ormiańskiej wspólnoty Mohylowa Podolskiego. Należy zauważyć, że zaproponowane w niniejszym artykule wnioski są wstępne, ponieważ istnieje możliwość odszukania jeszcze innych statystyk, przede wszystkim materiałów VII (1816) i X (1858) rewizji. Istnieją również dowody, że w latach 1821 i 1869 władze rosyjskie zbierały dodatkowe informacje dotyczące zmiany liczebności Ormian mohylowskich.

Stworzenie szeregów statystycznych na podstawie tych źródeł jest dość trudne. $Z$ jednej strony plusem jest to, że rejestrują one chronologicznie prawie jednakowe elementy sytuacji w odstępie 16-23 lat. Są to przedziały czasowe około jednego pokolenia, co umożliwia prześledzenie kluczowych wskaźników demograficznych - przyrostu naturalnego i migracyjnego, małżeństw itp. Z drugiej strony dane nie zawsze są kompletne i zawierają różnorodne informacje, co utrudnia lub uniemożliwia ich całościowe porównanie.

Dla przykładu, w inwentarzu z 1772 roku wypisano jedynie głowy osiadłych rodzin i sumy płaconego czynszu. Materiały rewizji z 1795 roku są chyba najbogatsze w informacje, ponieważ zawierają dane dotyczące nie tylko składu osiadłych i nieosiadłych rodzin, ale także ich zawodów, a nawet geografii pochodzenia ${ }^{7}$. Jednocześnie w materiałach nie odnotowano wszystkich mieszkańców i w ciągu następnych czterech lat były uzupełniane co najmniej dwa razy. Mimo to i tak pozostały luki co do całych rodzin lub poszczególnych ich członków, którzy zostali zapisani dopiero do następnej rewizji z 1811 roku. Ta z kolei rewizja wyróżniała się tym, że dokumentowano w niej jedynie mężczyzn i ich związek z poborem do wojska. Standaryzowane i podobne są tylko informacje rewizji $\mathrm{z}$ lat $1834 \mathrm{i} 1850$. Rejestrowano w nich pełny skład rodzin z zaznaczeniem wieku każdego członka rodziny, a także fakty przyrostu naturalnego i migracji - urodzenia, śmierci, przypadki emigracji i imigracji.

We wszystkich wskazanych dokumentach Ormianie Mohylowa Podolskiego występują jako osobna grupa podatkowa i społeczna w mieście, której status był umocowany prawnie. W dokumentach figurują pod nazwami: „Ormianie miasta

s. 196-201.

2 Центральний державний історичний архів України (dalej: ЦДІАУ), м.Київ: ф. 49, оп. 1, спр. 1855, арк. 5зв.

3 Державний архів Вінницької області (dalej: ДАВО) w Winnicy: ф. 177, оп. 1, спр. 810, арк. 1933в.-206.

4 ДАВО: ф. 177, оп. 1, спр. 1099, арк. 3-7.

${ }^{5}$ Ibidem, спр. 1138, арк. 289-305.

${ }^{6}$ Ibidem, спр. 1175, арк. 30зв.-49зв.

7 M. Potapenko, Ormianie Mohylowa Podolskiego w świetle materiałów V rewizji 1795 roku, „Lehahayer”, 6, 2019, s. 91-124. 
Mohylowa” (1795, 1850), „ormiańska społeczność fabrykancka” (1834), „Ormianie mohylowscy" (1869). Ta grupa statystyczna nie obejmowała wszystkich Ormian miasta. Na przykład w rewizji z 1795 roku duchowni ormiańskokatoliccy zostali wzięci pod uwagę w osobnym spisie rewizyjnym. Jednocześnie można założyć, że nie wszyscy członkowie wspólnoty byli etnicznymi Ormianami. Niewątpliwie poprzez otwarty „rynek narzeczonych” wchodziły do niej kobiety z zewnątrz, z innych wspólnot etnicznych miasta i spoza niego. Czasem pomyłkowo do ormiańskich spisów rewizyjnych trafiali ewidentni nie-Ormianie. Na przykład w uzupełnieniach do tej samej rewizji z 1795 roku przy niektórych nazwiskach (Wasiliew, Dmitriew, Petrow) znajduje się późniejsza uwaga „nie z Ormian”. Tak więc grupę tę należy rozpatrywać jako wspólnotę społeczną, której granice były podobne, ale nie pokrywały się całkowicie z granicami etnicznymi.

Ormianie Mohylowa Podolskiego posiadali odrębny samorząd gminny. W przebadanej do tej pory dokumentacji wymienieni są następujący wójtowie ormiańscy (w dokumentacji z czasów rosyjskich nazywani starostami): Eliasz Stefanowicz w 1772 roku $^{9}$, Żwaniecki i Piotr Aritonow w $1835 \mathrm{roku}^{10}$, Bohdan Żwaniecki i Todor Kałustowicz w 1850 roku $^{11}$ oraz Piotr Negrusz (syn Michała) w $1871 \mathrm{roku}^{12}$. Istniała także funkcja gminnego poborcy podatkowego. W 1850 roku sprawował ją Michał Negrusz ${ }^{13}$, prawdopodobnie ojciec ostatniego wójta. Warto zwrócić uwagę, że Ormianie byli uprzywilejowaną grupą mieszkańców miasta. W materiałach V rewizji figurują jako cudzoziemcy. Podstawą nadania tego statusu był przywilej ówczesnego właściciela miasta, Franciszka Salezego Potockiego, z 13 kwietnia 1743 roku, traktujący o zwolnieniu nowo przybyłych Ormian od „płacenia podatków i wykonywania różnych powinności”"14. Materiały VI rewizji wskazują na to, że faktycznie mohylowscy Ormianie cieszyli się istotnymi złagodzeniami w zakresie wykonania najbardziej uciążliwej powinności, jaką był pobór wojskowy. Spośród 141 osób płci męskiej, od tego obowiązku zwolnionych było 14 osób ze względu na status kupca i 22 osoby ze względu na status jedynego syna. Reszta, to jest 105 osób płci męskiej, została przydzielona do dalszych etapów rekrutacji, od 4 do 7 miejsca w kolejności. Znamienne, że Ormianie Mohylowa Podolskiego byli zwolnieni z pierwszych trzech kolejek rekrutacyjnych w sytuacji, gdy Rosja potrzebowała natychmiastowego uzupełnienia armii w związku z wojną toczoną w latach 1806-1812 z Turcją. W 1824 roku byli
8 ДАВО: ф. 177, оп. 1, спр. 810, арк. 207.
9 ЦДІАУ: ф. 49, оп. 1 , спр. 1855, арк. 5зв.
10 ДАВО: ф. 177, оп. 1, спр. 1138, арк. 3043в.-305.
${ }^{11}$ Ibidem, спр. 1175, арк. 483в.-49.
12 В. Григорян, История армянских колоний, s. 173.
13 ДАВО: ф. 177, оп. 1, спр. 1175, арк. 48зв.-49.
14 В. Микаелян, Четыре документа по истории могилевских армян, „Lpuptp huuupulquluid qhunnıpjnı\{ilıph” [Biuletyn Nauk Społecznych], 1978, 9, s. 103. 
całkowicie zwolnieni z poboru na podstawie decyzji Senatu z 27 maja 1808 roku o uwolnieniu z wojskowej służby cudzoziemców, którzy „zajmują się kunsztami w miastach i wsiach"15.

W 1851 roku rada miejska Mohylowa podjęła decyzję o wykluczeniu z IX rewizji osobnego wykazu Ormian ${ }^{16}$. Była to pierwsza udokumentowana próba pozbawienia ich przywilejów. Począwszy od 1858 roku, a najczęściej podczas $\mathrm{X}$ rewizji, do Podolskiej Izby Państwowej wielokrotnie zgłaszali się chętni do opuszczenia gminy ormiańskiej Mohylowa ${ }^{17}$. W 1869 roku zostało to wykorzystane przez generała-gubernatora kijowsko-podolsko-wołyńskiego jako pretekst dla likwidacji gminy i pozbawienia jej głównego przywileju - zwolnienia od rekrutacji do wojska. W wyniku przeprowadzonego dochodzenia zostało ustalone, że „stracili fach” i ze względu na długie osiedlenie nie mogą być uznawani za „cudzoziemskich osadników"18. Na podstawie tego orzeczenia minister spraw wewnętrznych wydał nakaz obowiązkowego wykonywania powinności wojskowych przez Ormian mohylowskich, zatwierdzony przez Radę Ministrów 9 marca 1871 roku $^{19}$. Utratę przywilejów Ormian mohylewskich trzeba rozpatrywać w kontekście zachodzącego w całym imperium procesu likwidacji dawnych handlowych wspólnot „cudzoziemców”. Niemal jednocześnie z Ormianami Mohylowa Podolskiego przywileje utracili Ormianie w Nachiczewanie nad Donem, Starym Krymie i Karasubazarze oraz Grecy w Niżynie i Mariupolu.

Tak więc nadal w latach 1795-1871 Ormianie byli osobną uprzywilejowaną gminą Mohylowa Podolskiego. Określenie „mohylowscy Ormianie”, podobnie jak na przykład „niżyńscy Grecy”, oznaczało lokalną grupę populacji o specjalnym statusie prawnym. Władze Rosji próbowały podtrzymać jej istnienie, licząc na pozytywny efekt w postaci napływu zagranicznych osadników do pogranicznego miasta. Można założyć, że specyficzny i uprzywilejowany status Ormian Mohylowa Podolskiego odegrał ważną rolę w wyznaczeniu w 1810 roku tego właśnie miasta na rezydencję jedynego na obszarze Rosji ormiańskokatolickiego biskupa, Józefa Krzysztofowicza.

Najbardziej wiarygodnym szeregiem statystycznym, choć dalekim od kompletności, są informacje o dynamice liczebności Ormian mohylowskich. Należy tu uwzględnić trzy kluczowe parametry: liczbę gospodarstw domowych, łączną liczbę członków gospodarstw domowych, płeć. Pierwsze dwa spisy nie dostarczają kompletnej informacji o liczebności gospodarstw domowych. W inwentarzu z 1772 roku uwzględniono tylko osiadłe gospodarstwa domowe. Z kolei materiały rewizji z 1795 roku, jej uzupełnienia i poprawki, dają możliwość ustalenia

15 Ibidem, s. 101.

16 ДАВО: ф. 177, оп. 1, спр. 1175, арк. 49зв.

17 В. Микаелян, Четыре документа, s. 101.

18 ЦДІАУ: ф. 442, оп. 48, спр. 184, арк. 9.

19 В. Микаелян, Четыре документа, s. 105. 
prawdopodobnej minimalnej liczby osiadłych gospodarstw domowych i nieosiadłych Ormian. Podczas rewizji z 1811 roku uwzględnione były tylko gospodarstwa domowe z mężczyznami podlegającymi poborowi wojskowemu, a także nie zanotowano informacji o gospodarstwach domowych wdów. Dopiero dwa ostatnie spisy (1834 i 1850) dostarczają wyczerpujących informacji na ten temat.

Tabela 1. Liczebność Ormian Mohylowa Podolskiego w latach 1772-1850

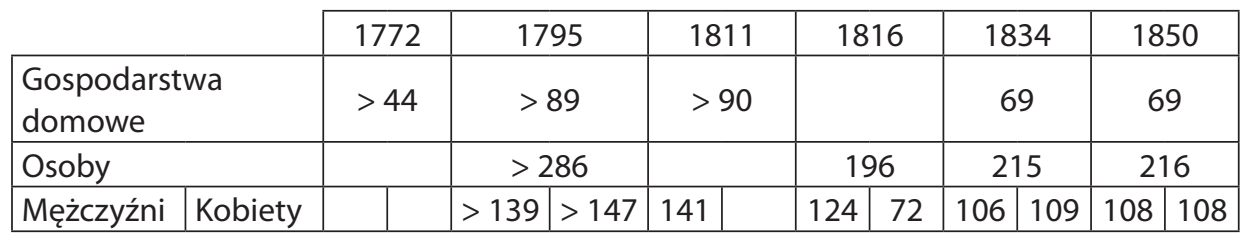

Można więc stwierdzić, że w latach 1772-1811 liczba gospodarstw domowych wzrosła od co najmniej 44 do 90, a następnie zmniejszyła się do 69 i ustabilizowała na tym poziomie w latach 1834-1850. Znamienne, że ta oficjalna liczba ormiańskich rodzin jest wyższa niż dane o. Minasa Bżyszkianca, który w 1820 roku naliczył w Mohylowie Podolskim 60 ormiańskich rodzin ${ }^{20}$. Wahania liczby gospodarstw domowych korelowały z ogólną liczbą Ormian, członków tych gospodarstw. Odnośny wskaźnik zmalał z co najmniej 286 osób w 1795 roku do 215 osób w 1834 roku. Dowodem na to, że liczba Ormian i ich rodzin była relatywnie stabilna, jest fakt, że liczba mężczyzn była prawie stała i nie wahała się znacząco w latach 30.-50. XIX wieku. W 1834 roku było 106 mężczyzn, w $1850-108$, w $1859-101$, w $1869-109$.

Informacje te są ważne, ponieważ prostują tezę wprowadzoną do obiegu naukowego przez Władysława Poboga-Górskiego, że Ormianie stanowili prawie połowę mieszkańców Mohylowa Podolskiego ${ }^{21}$. W rzeczywistości procentowo najwięcej było ich w 1795 roku, ale i wtedy stanowili zaledwie około 6\% mieszkańców miasta, czyli znacznie ustępowali liczbie Żydów (38\%), Ukraińców (35\%) i Greków (12\%).

Porównanie materiałów VIII i IX rewizji pozwala odtworzyć kluczowe demograficzne cechy Ormian Mohylowa Podolskiego. Wspólnota ta, po pierwsze, wykazywała stosunkową równowagę płciową, była zasiedziała i zintegrowana ze społeczno-gospodarczym środowiskiem miasta. Po drugie, była młoda i zdolna do pracy, gdyż w latach 1834-1850 udział osób w wieku do 29 lat wzrósł w niej z 55 do 59\%, w 1834 roku ponad 25\% członków stanowiły dzieci w wieku do 9 lat, a ogółem około 60\% to osoby w wieku produkcyjnym (15-59 lat).

20 В. Григорян, История армянских колоний, s. 172.

${ }^{21}$ W. Pobóg-Górski, Powiat mohylowski w guberni podolskiej. Opis geograficzno-historyczny wszystkich miast i miasteczek, wsi, przysiołków, futorów, słowem zaludnionych miejscowości w tym powiecie, z dodaniem odpowiednych dokumentów, Kraków 1902, s. 208. 
Po trzecie, wskaźniki śmiertelności, szczególnie dziecięcej, były stosunkowo niskie i nie przewyższały średnio 4 zgonów na rok, więc mniej niż 2\% ogólnej liczby wspólnoty. Jednak notujemy też gwałtowne wzrosty śmiertelności, pierwszy w latach 1830-1831 (13 zgonów) i drugi w latach 1847-1848 (12 zgonów). Możliwe, że były one spowodowane przez choroby epidemiczne, głównie cholerę ${ }^{22}$.

Tabela 2. Struktura płci i wieku Ormian Mohylowa Podolskiego (według danych z VIII i IX rewizji)

\begin{tabular}{|l|c|c|c|c|}
\hline \multirow{2}{*}{$\begin{array}{c}\text { Grupa } \\
\text { wiekowa }\end{array}$} & \multicolumn{2}{|c|}{ 1834 rok } & \multicolumn{2}{c|}{ 1850 rok } \\
\cline { 2 - 5 } & Mężczyźni & Kobiety & Mężczyźni & Kobiety \\
\hline 0-9 lat & 24 & 32 & 17 & 19 \\
\hline 10-19 lat & 13 & 24 & 27 & 21 \\
\hline 20-29 lat & 14 & 11 & 19 & 24 \\
\hline 30-39 lat & 25 & 22 & 13 & 17 \\
\hline 40-49 lat & 12 & 7 & 8 & 16 \\
\hline 50-59 lat & 10 & 10 & 17 & 7 \\
\hline 60-69 lat & 5 & 2 & 5 & 3 \\
\hline 70-79 lat & 3 & 0 & 2 & 1 \\
\hline 80-89 lat & 0 & 1 & 0 & 0 \\
\hline
\end{tabular}

W zmianach liczebności Ormian Mohylowa Podolskiego ważną rolę odegrały czynniki związane nie tylko z przyrostem naturalnym, ale i migracjami. Pod tym drugim względem ich wspólnota była otwarta i aktywna w obu kierunkach: na migracje przychodzące i wychodzące. Jak już wspomniałem, dane z V rewizji dokumentują geografię pochodzenia większości rodzin, co najprawdopodobniej oznacza, że były one nowo przybyłe. Geografia ta była szeroka, ale najwięcej rodzin pochodziło z Galicji. Spowodowane przez rozbiory Polski wytyczenie nowej granicy (rosyjsko-austriackiej) naruszało ustalone stosunki ekonomiczne i społeczne, a także wywołało falę migracji. Do połowy XIX wieku skład gminy ormiańskiej w Mohylowie był w dalszym ciągu uzupełniany głównie kosztem migrantów z Galicji. Rewizja z 1811 roku udokumentowała przybycie ,zza granicy" dwóch Ormian - Onufrego Wincyna i Jakuba Majewskiego ${ }^{23}$. W 1820 roku Podolski Zarząd Gubernialny włączył w skład gminy Jakuba Michajłowskiego ${ }^{24}$. W 1823 roku był w niej zapisany Tadeusz Tatusewicz z żoną Elżbietą ${ }^{25}$, a w 1831 roku - Teodor Wartanowicz ${ }^{26}$. Między 1859 i 1869 rokiem do mohylowskich Ormian zapisano jeszcze 8 osób „z dawnej polskiej szlachty”27. Tak więc za czasów

22 В. Григорян, История армянских колоний, s. 172.

23 ДАВО: ф. 177, оп. 1, спр. 1099, арк. 7.

${ }^{24}$ Ibidem, спр. 1138, арк. 303зв.

25 Ibidem.

${ }^{26}$ Ibidem, арк. 302зв.

27 ЦДІАУ: ф. 442, оп. 48, спр. 184, арк. 8зв. 
przynależności Mohylowa Podolskiego do Rosji miejscowa wspólnota ormiańska epizodycznie tylko uzupełniana była przez przybyszy z austriackiej Galicji. $\mathrm{Na}$ domiar tego ormiańskie pochodzenie części z nich jest wątpliwe.

Skala odpływu Ormian z Mohylowa Podolskiego była znacząco większa. Posiadamy informacje o wyjściu z ich gminy w latach 1795-1843 co najmniej 42 osób. Znamienne jest, że zdecydowana większość z nich (31 osób) uciekła. Były tylko dwa przypadki oficjalnego wyłączenia ze społeczności. Mowa o przypadku Grzegorza Piaseckiego z sześcioma synami i dwoma braćmi w 1811 roku $^{28}$, a także Kajetana Sadowskiego, który w 1818 roku udał się na służbę do Besarabskiego Zarządu Okręgowego ${ }^{29}$. Jedna kobieta - Katarzyna Mikołajowa (Katarina Nikołajewa) - została zesłana w 1843 roku na Syberię $e^{30}$. Dla części uciekinierów status członka ormiańskiej gminy w Mohylowie był łatwym instrumentem naturalizacji w Rosji, jednak większość ucieczek była umotywowana względami ekonomicznymi.

Tabela 3. Pochodzenie geograficzne rodzin ormiańskich Mohylowa Podolskiego według danych V rewizji z 1795 roku

\begin{tabular}{|l|c|l|}
\hline Skąd przybyły & Liczba & \multicolumn{1}{|c|}{ Nazwiska, ,rewizyjne" rodzin } \\
\hline «z Halicyi» ${ }^{11}$ & 44 & $\begin{array}{l}\text { Ambroziew, Azbiewicz, Baranowicz, Baroncz, Czajkow- } \\
\text { ski, Czurdin, Danilow, Demianow, Donigiewicz, Grigoriew, } \\
\text { Hłuszkiewicz, Hortkow, Iwanow, Juriew, Kaluszowski, Krisz- } \\
\text { toforow, Krysztoforow, Kucki, Lisecki, Markow, Negrusz, Ni- } \\
\text { kołajew, Piasecki, Popiel, Sadowski, Sieracki, Tesmieniecki, } \\
\text { Tumanow, Żwaniecki }\end{array}$ \\
\hline «z Azyi» & 9 & Darabidow, Gajdarow, Jeremejew, Michaildski \\
\hline «z Armenij» & 6 & Jakubow, Kiworkow, Nikołajew, Periow, Semenow, Tosunow \\
\hline «z Turcyi» & 6 & $\begin{array}{l}\text { Aleksandrowicz, Darabidow, Kasperow, Kristoforow, } \\
\text { Sarkisow }\end{array}$ \\
\hline «z Moldawij» & 5 & Baron, Kałustow \\
\hline «z Wengier» & 3 & Samojłow \\
\hline «z Bosnij» & 1 & Łatyna \\
\hline
\end{tabular}

Komisarze rewizyjni guberni podolskiej stwierdzili urzędowo wykonywanie przez Ormian mohylewskich nisko dochodowych i stagnacyjnych branż - wyrobu safianu i wytopu tłuszczu. Na przełomie wieków XVIII i XIX należało do nich 15 z 19 topialni tłuszczu i fabryk safianu w tym mieście. W różny sposób było z tymi zajęciami związane życie co najmniej połowy ormiańskich rodzin.

28 ДАВО: ф. 177, оп. 1, спр. 1099, арк. 3.

29 Ibidem, спр. 1138, арк. 298зв.

30 Ibidem, спр. 1175, арк. 39.

${ }^{31}$ Do tej grupy wliczono też prawdopodobnie rodziny pochodzące z Kamieńca Podolskiego. 
Wszystkie ormiańskie zakłady w 1805 roku na wyrobie safianu zarobiły zaledwie 1380 rubli, a na wytapianiu tłuszczu poniosły straty w wysokości 3970 rubli $^{32}$. Upadek obu branż był spowodowany szybkim spadkiem popytu na safian, obuwie, które wyszło z mody. Dlatego też ormiańscy rzemieślnicy nie zajmowali się wprowadzaniem innowacji technicznych w produkcji i pragnęli zmienić zawód. Niegdyś prestiżowa przynależność do „ormiańskiej wspólnoty fabrykanckiej” stała się statusem obciążającym prawnie.

Również zmiana granic pod koniec XVIII wieku spowodowała utratę przez Mohylów Podolski statusu znaczącego ośrodka handlu tranzytowego między Polską a Rosją. To z kolei doprowadziło do odpływu z miasta kapitału ormiańskiego. W 1795 roku w gminie ormiańskiej były 4 rodziny kupieckie pierwszej gildii (Antoni Barącz, Filip Semenow, Bohdan Periow, Gawryło Kiworkow) i jedna rodzina kupiecka trzeciej gildii (Kajetan Samojłow) ${ }^{33}$. W 1811 roku pozostała tylko jedna rodzina kupiecka pierwszej gildii (Jan Petrow) i dwie rodziny kupieckie trzeciej gildii (Mikołaj Azbiew i Grzegorz Piasecki, który w tymże roku opuścił szeregi wspólnoty) ${ }^{34}$. Porównanie inwentarza z 1772 roku i rewizji z 1795 roku pozwala sformułować przypuszczenie, że utrata handlowego znaczenia spowodowała radykalną zmianę struktury gminy pod koniec XVIII wieku. Wyjeżdżały przeważnie rodziny, które zajmowały się handlem, natomiast przybywały rodziny, które specjalizowały się w wyrobie safianu. Do 1795 roku z Mohylowa Podolskiego wyjechała około połowa z 44 rodzin, których zamieszkanie dokumentował inwentarz z 1772 roku. Z miasta znikają rodziny zapisane pod określeniami i nazwiskami: Horodeński, Kupiec, Manukiewicz, Muntian, Stambulczyk, Tabacznik ${ }^{35}$. Natomiast absolutna większość nowo przybyłych rodzin była związana z wyrobnictwem safianu (zostali zarejestrowani jak „fabrykanci”, „rzemieślnicy”, „komornicy”, „robotnicy”).

Osobno należy zwrócić uwagę na małżeństwa Ormian Mohylowa Podolskiego. Średni wiek zawarcia małżeństwa był typowy dla miast tego regionu - dla mężczyzny wynosił 25-30 lat, dla kobiet 20-25 lat. Większość rodzin była nuklearna, czyli składała się z rodziców i ich dzieci, przeważnie niepełnoletnich. W rezultacie ciągłego wyrastania $\mathrm{z}$ nich nowych rodzin nuklearnych powstawały rozgałęzione rody: Barączów, Garabidowiczów, Nikołajewych, Gajdarowych-Petrowych, Negruszów-Jakowlewych, Kuckich-Czackich-Łuckich i innych. Porównanie wszystkich zgromadzonych informacji statystycznych świadczy, że na „rynku narzeczonych” pierwszeństwo miały kobiety, które pochodziły z ormiańskich rodzin Mohylowa Podolskiego. W ten sposób łączyli się Negruszowie z Piaseckimi, Aleksandrowiczowie z Barączami, Hłuszkiewiczowie i Tatusiewi-

32 ДАВО: ф. 475, оп. 1, спр. 14, арк. 19-21.

33 ДАВО: ф. 177, оп. 1, спр. 810, арк. 1933в.-194зв.

34 Ibidem, спр. 1099, арк. 3.

35 ЦДІАУ: ф. 49, оп. 1, спр. 1855, арк. 5зв. 
czowie z Nikołajewami, Azbiewiczami, Popielami. Na „rynku narzeczonych” występowały także Ormianki spoza Mohylowa Podolskiego. Liczebnie przeważały małżonki noszące popularne wśród Ormianek kobiece imiona (Kajetana, Rozalia, Urszula) albo miały ormiański patronimik - córki Kajetanów, Wartanów, Aswadurów, Mygyrdyczów, Keworków, Sarkisów. Tak więc Ormian mohylowskich można scharakteryzować jak grupę korporacyjną, dla której endogamia (śluby wewnątrz własnej etniczności) była instrumentem określenia i zachowania granic wspólnoty.

Lista imion męskich i żeńskich jest ubocznym świadectwem, że absolutna większość mohylowskich Ormian należała do Kościoła ormiańskokatolickiego i ciążyła ku polskiej kulturze. Na przykład popularne były niewystępujące u prawosławnych świętych katolickie imiona, takie jak Gertruda, Dominik, Kasper. Znamienne, że nie zważając na celową i natarczywą rusyfikację imion podczas sporządzania spisów rewizyjnych i innych oficjalnych dokumentów, niejednokrotnie powtarzały się przypadki nalegania na udokumentowanie łacińskich transkrypcji imion - „Jan” zamiast „Iwana”, „Jakub” zamiast „Jakowa”, „Stefan” zamiast „Stepana” itd. Jeden z wójtów gminy, zapisany jako Iwan Żwaniecki (czasami Zwaniecki), w dokumentach na swej pieczątce miał inicjały «J. Ż.», utworzone od polskiej wersji swego imienia: «Jan Żwaniecki» ${ }^{36}$. Tak samo nieudaną okazała się rusyfikacja nazwisk. O ile w V i VI rewizji zazwyczaj znajdujemy formy z końcówką „-ow”, „-ew”, o tyle w IX rewizji zmieniały się one na formy z końcówką „,-icz”. Na przykład zamiast „Azbiew” - „Azbiewicz”, zamiast „Garabidow” - „Garabidowicz”.

Wspomniane wcześniej pogorszenie sytuacji ekonomicznej było silnym czynnikiem językowej asymilacji Ormian w Mohylowie i zatraty odrębności kulturowej. Spisy rewizyjne z lat 1795 i 1811 były ostatnimi, pod jakimi przedstawiciele ormiańskiej wspólnoty podpisywali się w języku ormiańskim. W 1826 roku ustała tradycja wpisów ormiańskich w księgach metrykalnych kościoła pod wezwaniem Niepokalanego Poczęcia Najświętszej Maryi Panny ${ }^{37}$. Według świadectwa Lewona Mazirianca, do lat 90. XIX wieku „mohylowscy Ormianie utracili język” i w przeważającej części „znają [tylko] kilka ormiańskich słów”38. Język rosyjski, przynajmniej w pisemnym wariancie, był cudzy i słabo zrozumiały. W 1850 roku wójtowie gminy ormiańskiej nie byli w stanie, z powodu analfabetyzmu, własnoręcznie podpisać się pod spisem rewizyjnym. Pełnomocnictwo w tym zakresie dali Iwanowi Hłuszkiewiczowi ${ }^{39}$.

Wszystkie te dane statystyczne, ustalone dzięki zachowaniu się dokumentacji rewizji rosyjskich, są wartościowym źródłem dla poznania dziejów jednej

36 ДАВО: ф. 177, оп. 1, спр. 1138, арк. 311.

37 В. Григорян, История армянских колоний, s. 167.

38 Cyt. za: ibidem, s. 173.

39 ДАВО: ф. 177, оп. 1, спр. 1175, арк. 49. 
z niewielu miejskich gmin ormiańskich, która pod władzą Rosji przez długi czas zachowywała odrębny status społeczny i samorząd. Opracowanie tych źródeł pozwala nie tylko udokumentować liczebność Ormian mohylowskich i szczegóły ich adaptacji do nowej porozbiorowej sytuacji ekonomicznej i politycznej, ale też w znacznym stopniu zrekonstruować skład osobowy tej gminy, co najmniej 600 osób z ponad 70 rodzin (zob. tabelę 4). O ile wcześniej znanych było zaledwie około 10 nazwisk ormiańskich rodzin z Mohylowa, o tyle otwiera się teraz perspektywa pełnej rekonstrukcji rodzinnego i personalnego składu gminy w tym mieście od schyłku XVIII do połowy XIX wieku. 
Tabela 4. Rodziny Ormian zamieszkałych w Mohylowie Podolskim w latach 1795-1850 w świetle materiałów V, VI, VIII i IX rewizji

Objaśnienia:

1) W pierwszej kolumnie (nazwisko) cyframi rzymskimi oznaczono następujące materiały rewizji:

V - spis rewizyjny Ormian Mohylowa Podolskiego z 17 lipca 1795 roku;

Va - uzupełnienie do spisu rewizyjnego z 1795 roku, nr 1 (1795-1799);

$\mathrm{Vb}$ - uzupełnienie do spisu rewizyjnego z 1795 roku, nr 2 (1795-1799);

VI - spis rewizyjny Ormian Mohylowa Podolskiego z 29 września 1811 roku;

VIII - spis rewizyjny Ormian Mohylowa Podolskiego z 25 kwietnia 1834 roku;

VIIIa - uzupełnienie do spisu rewizyjnego z 1834 roku, nr 1 z 27 października 1834 roku;

VIIIb - uzupełnienie do spisu rewizyjnego z 1834 roku, nr 2 z maja 1835 roku;

IX - spis rewizyjny Ormian Mohylowa Podolskiego z 20 sierpnia 1850 roku.

2) W następnych pięciu kolumnach podano przedstawicieli danej rodziny od 1. do 5. pokolenia. Za nazwiskami, w nawiasach kwadratowych, dodano informacje o osobach pozostających w pokrewieństwie i na stałe zamieszkałych przy tej rodzinie:

[b] - brat;

[br] - bratanek/bratanica;

[k] - krewny/krewna;

[m] - matka;

[p] - pracownik;

[s] - siostra;

[w] - wychowanek/wychowanka.

3) Nazwiska podano w formie przyjętej w większości pomiarów statystycznych (spisów rewizyjnych) albo użytej w ostatnim z nich - IX. W nawiasach podano inne formy nazwisk albo nazwiska używane przez linie boczne rodziny.

4) W przypadku występowania odmiennych form pisowni imienia tej samej osoby w różnych spisach rewizyjnych, w tabeli zastosowano rzymskokatolicką (polską) tradycję jej zapisu, na przykład:

«Jan» zamiast «Ogan», «Iwan»;

«Tomasz» zamiast «Tymosz», «Tymofij»;

«Krzysztof» zamiast «Chrystofor», «Krzysztofor».

5) Po znaku „+" kursywą podane zostały imiona i lata życia żony/żon.

6) W nawiasach podano przybliżone lata życia danej osoby z możliwym błędem \pm 1 rok. Wynika to $\mathrm{z}$ faktu, że w spisach rewizyjnych nie dokumentowano dat urodzenia albo śmierci, a tylko wiek w momencie przeprowadzenia spisu. Niepełne informacje o latach życia podano w następujący sposób:

(?-1800) - roku urodzenia nie ustalono;

(1800-?) - roku śmierci nie ustalono.

7) W tabeli ukazano jedynie informacje biograficzne ze spisów rewizyjnych. Nie porównywano ich $\mathrm{z}$ innymi źródłami. 


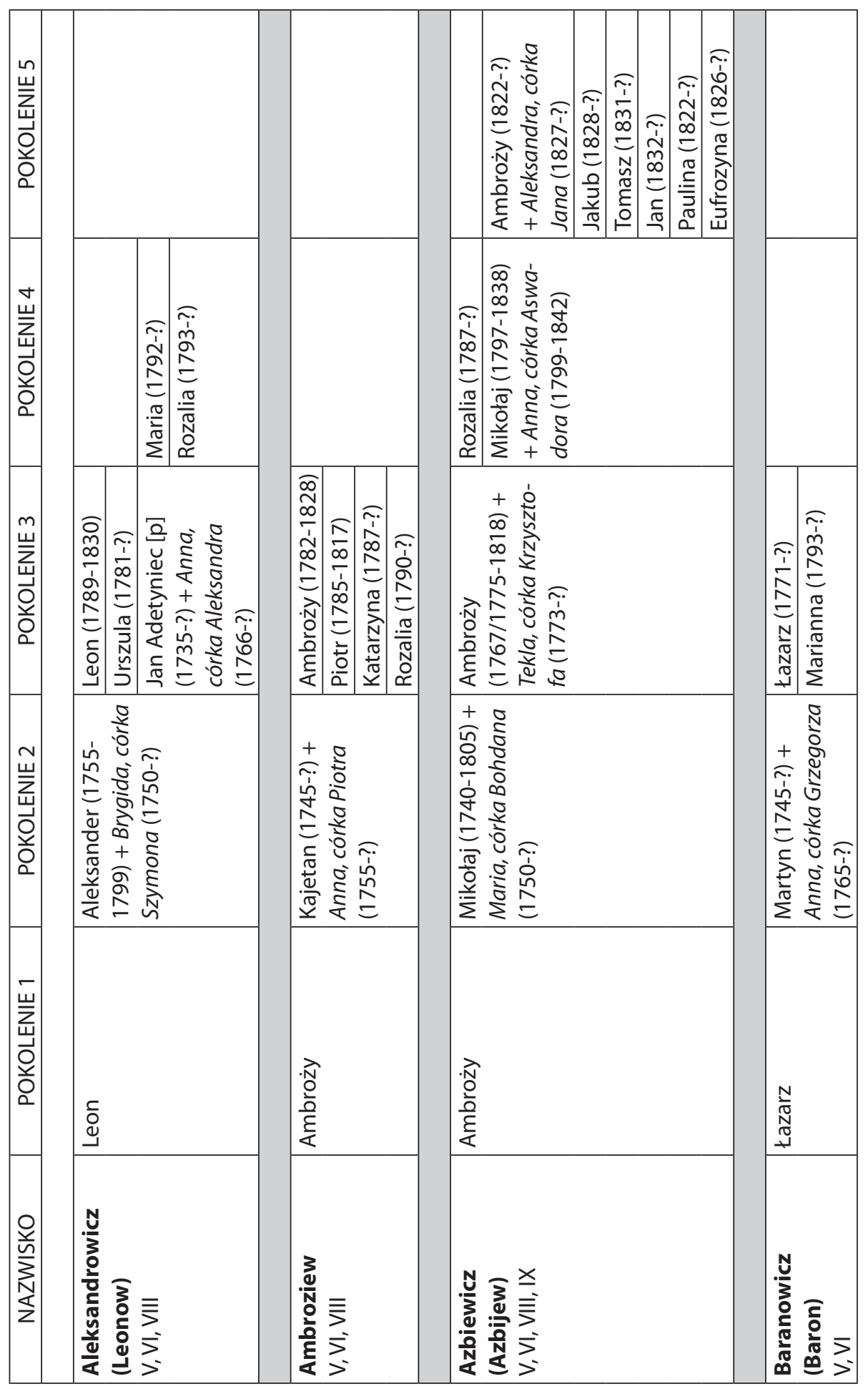




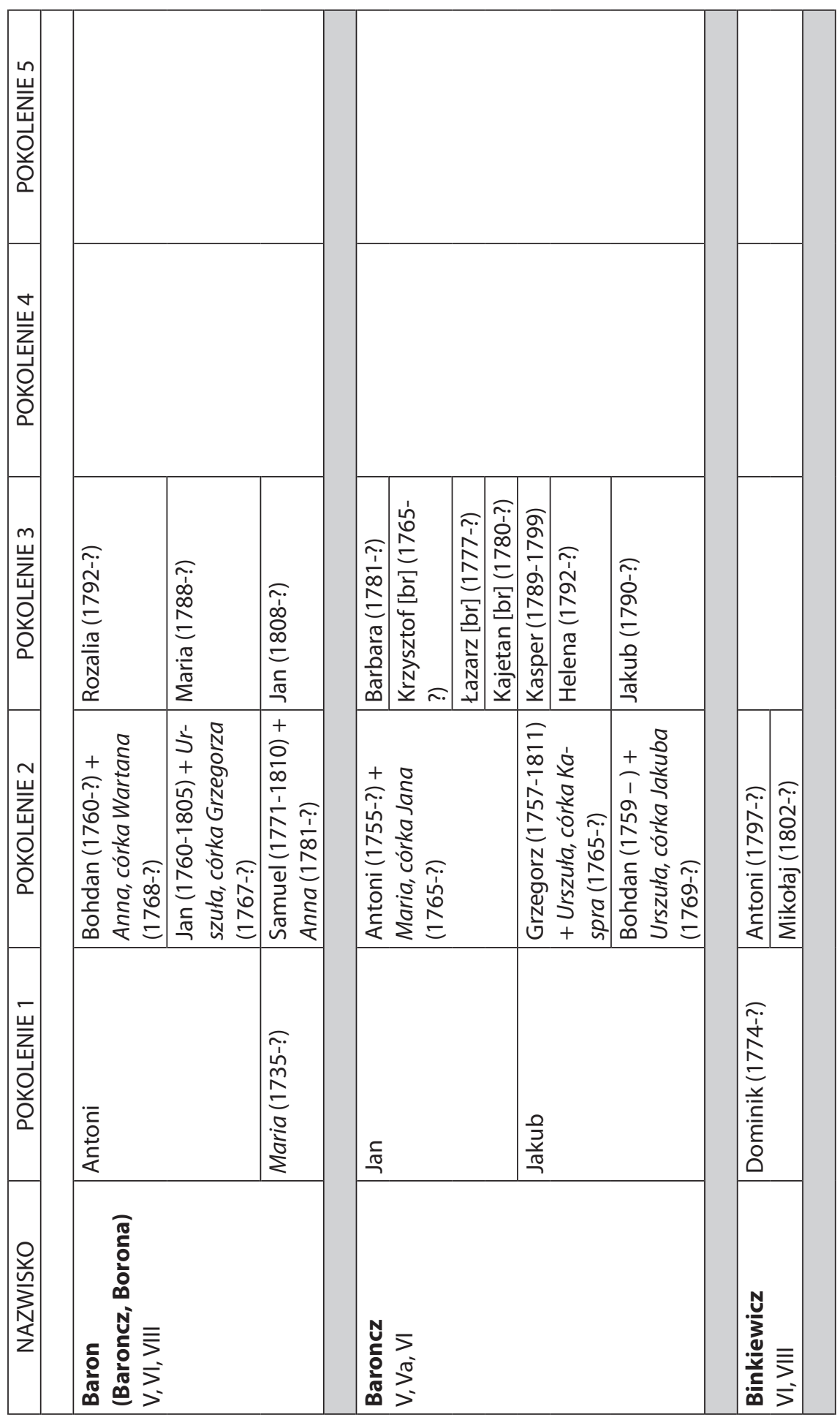




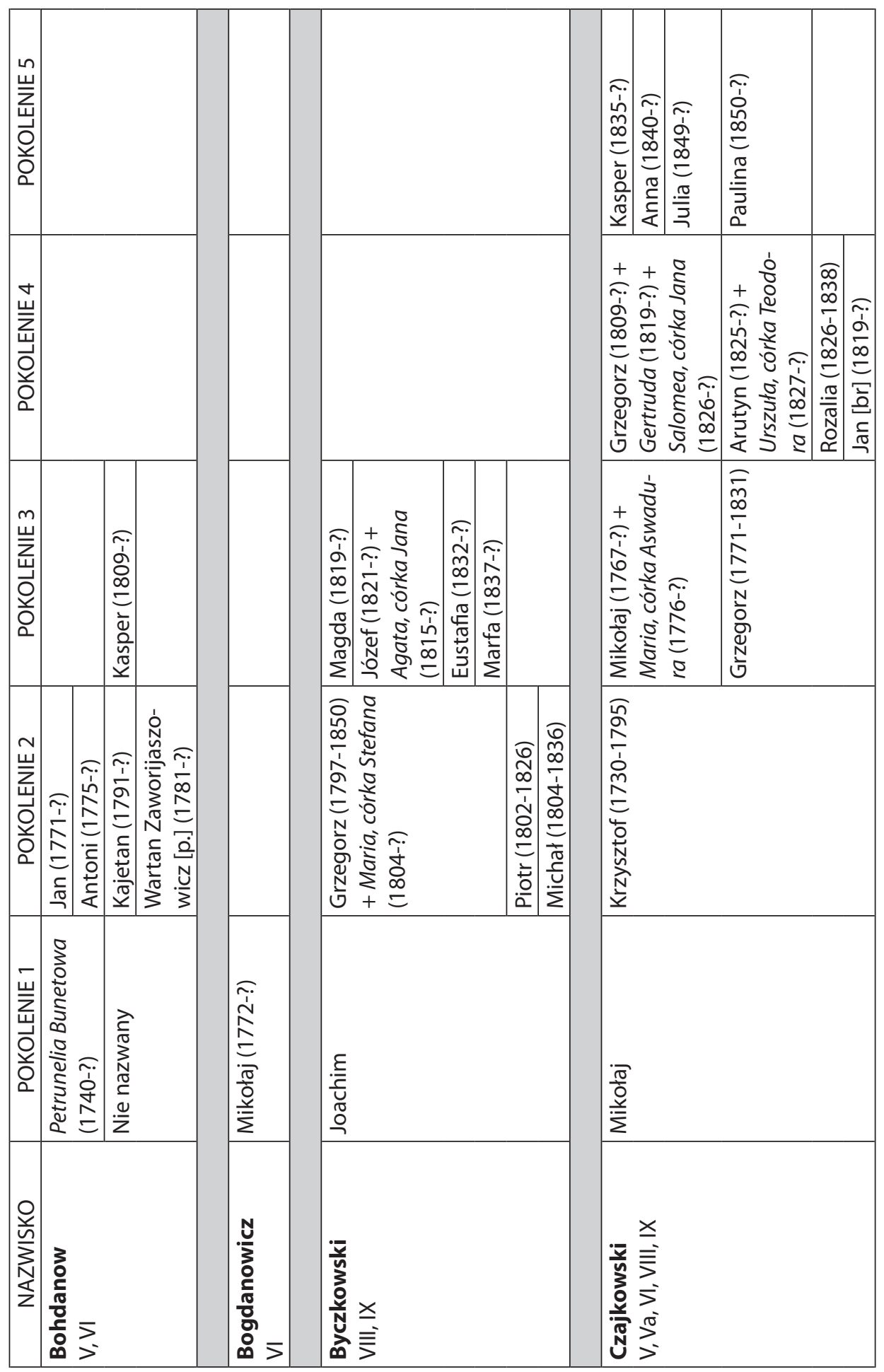




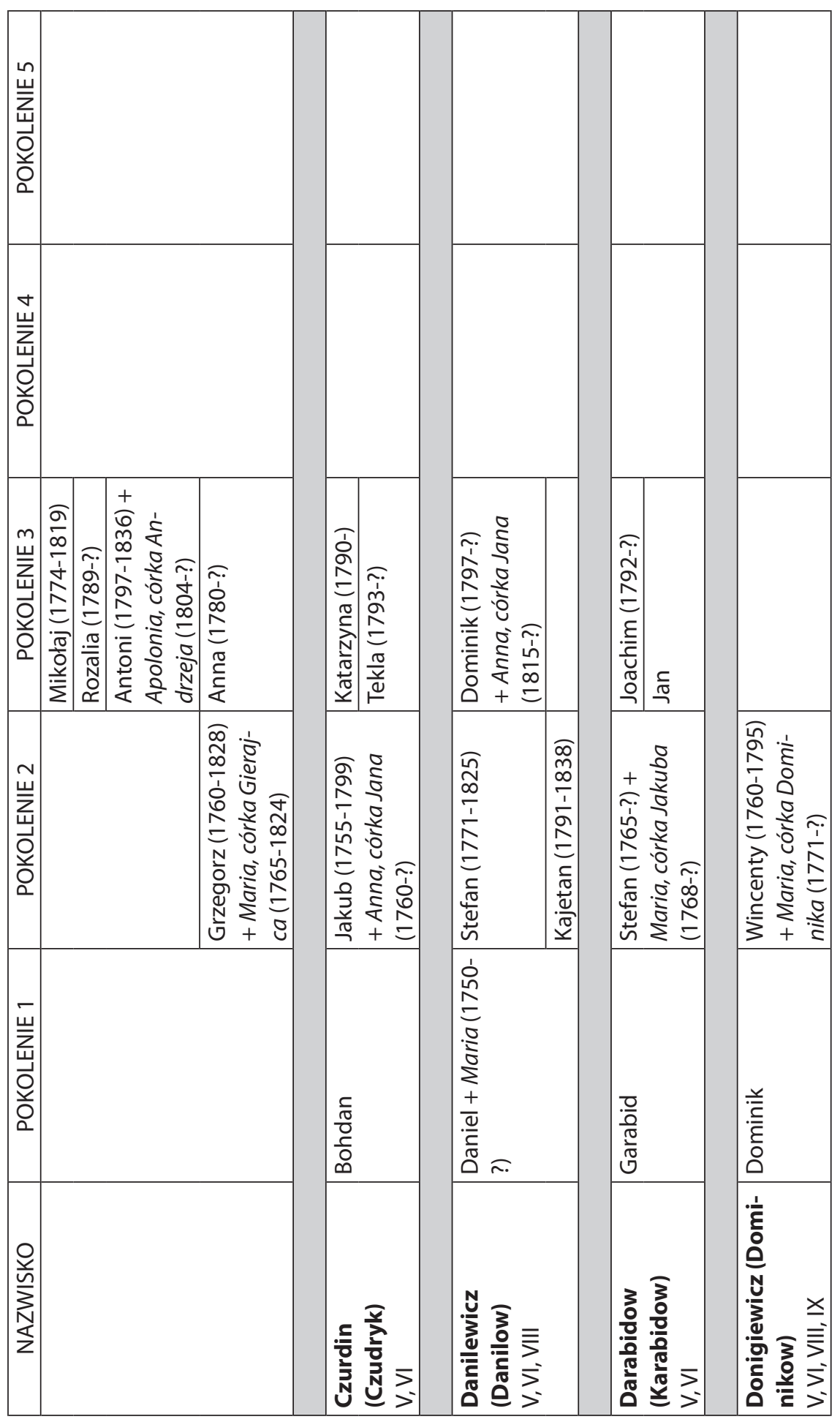




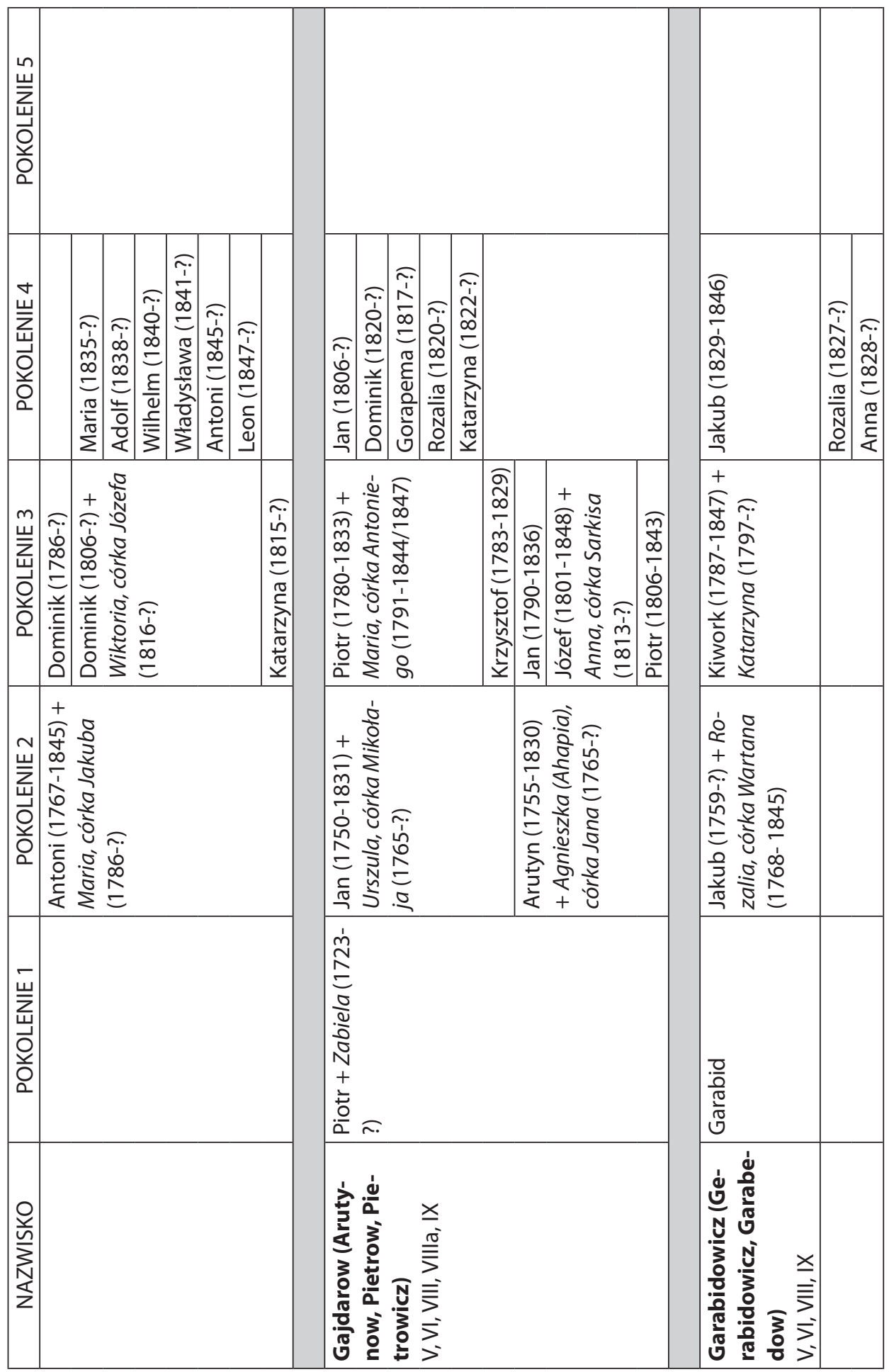




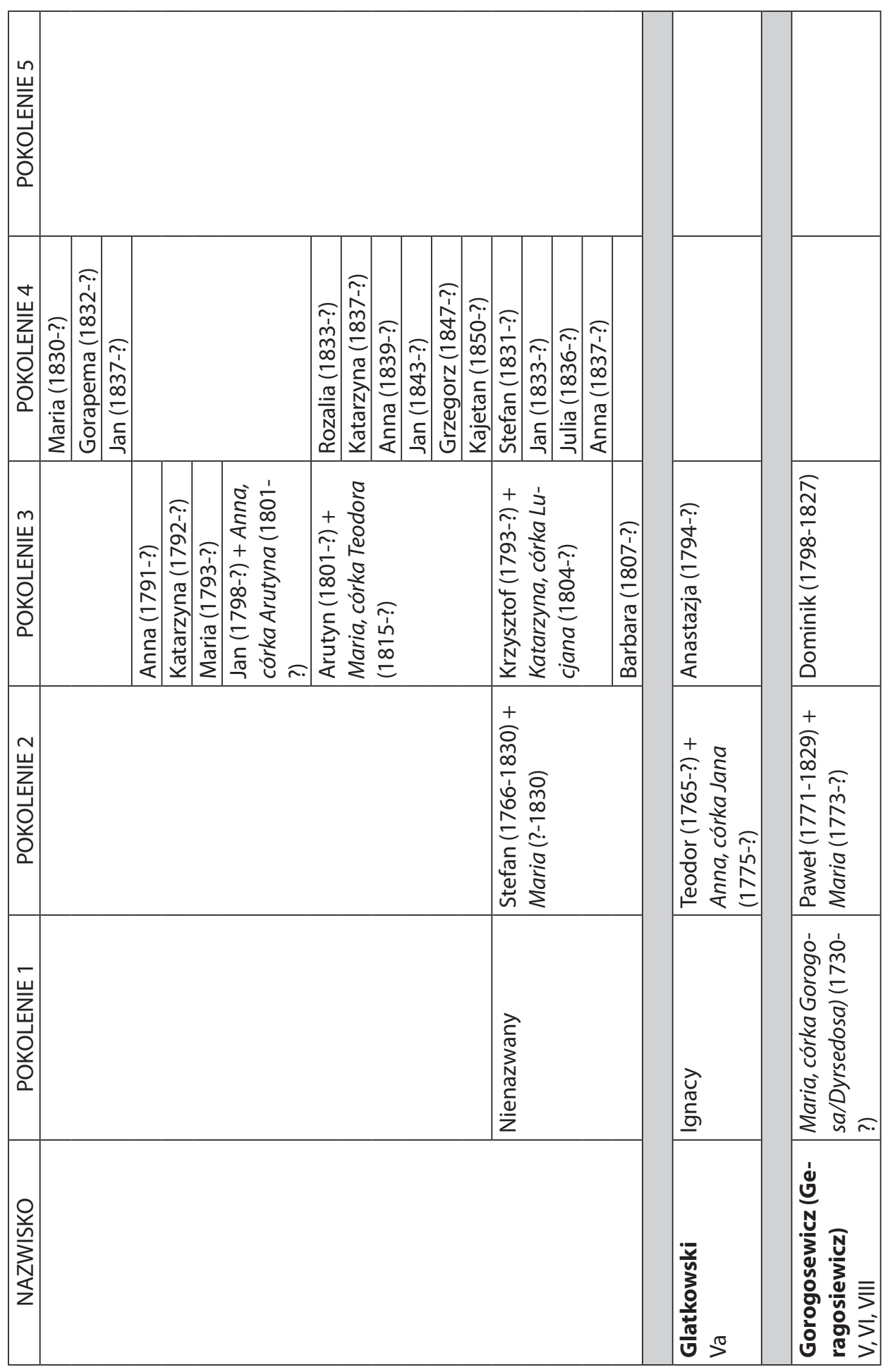




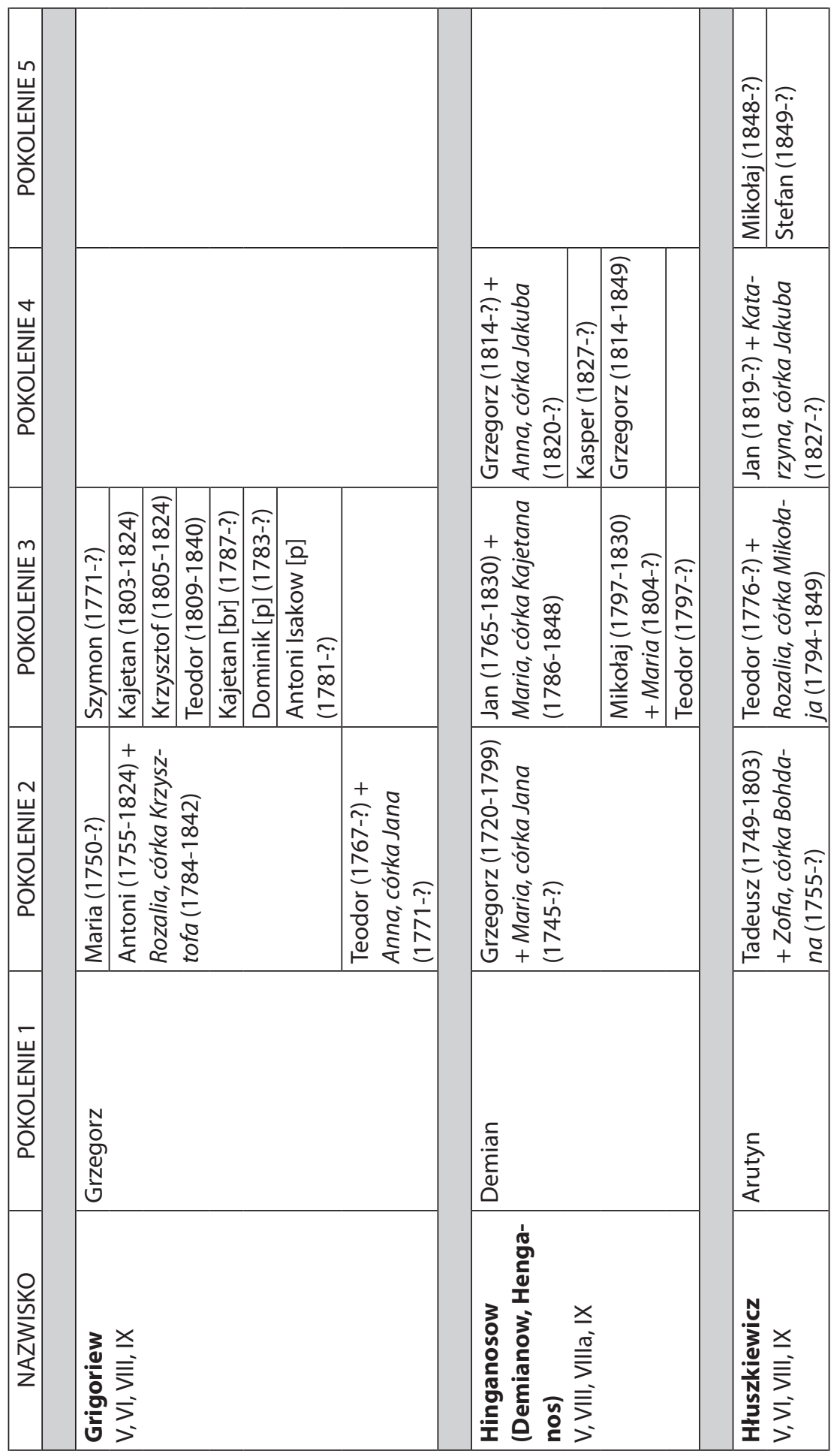




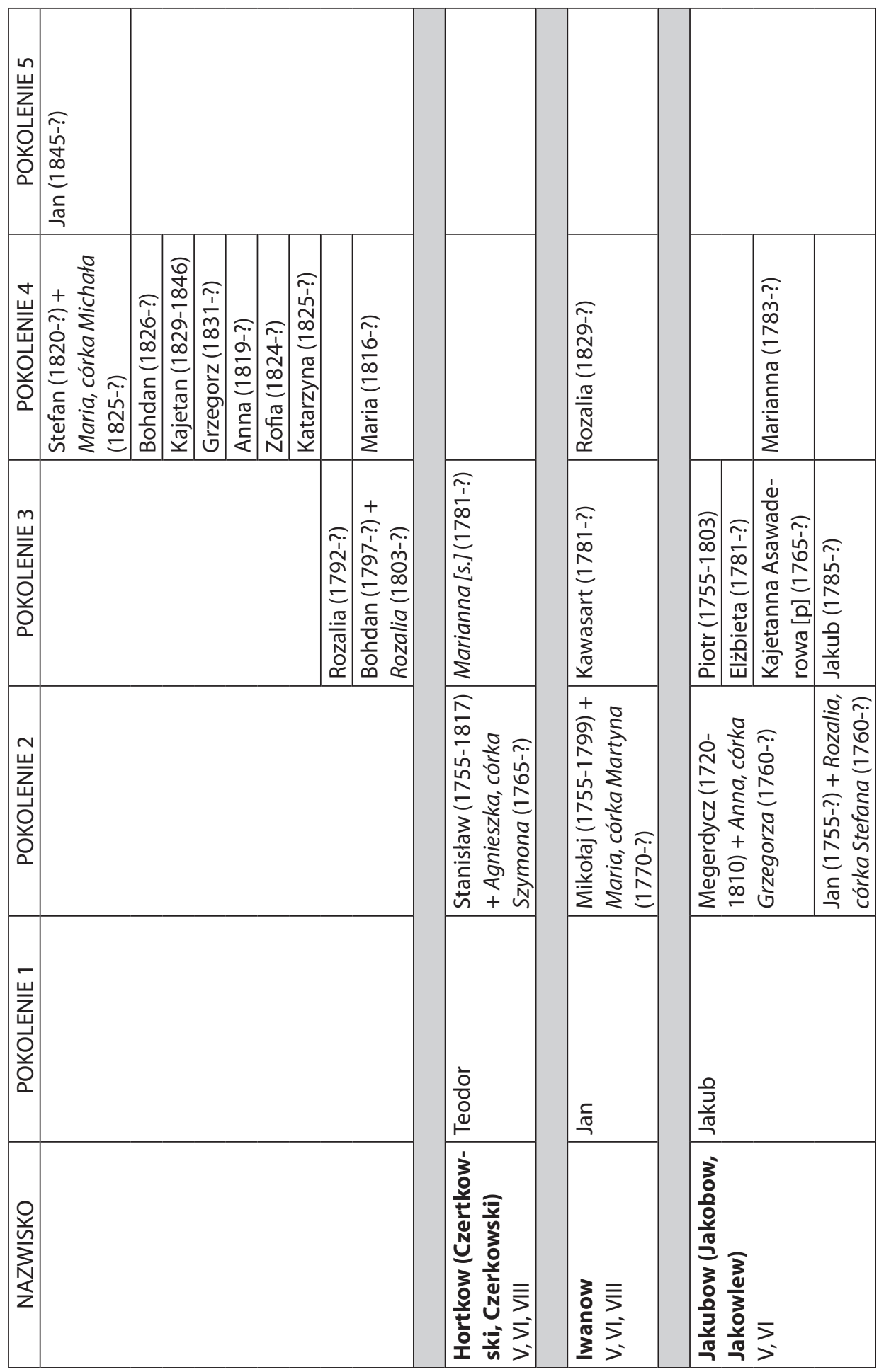




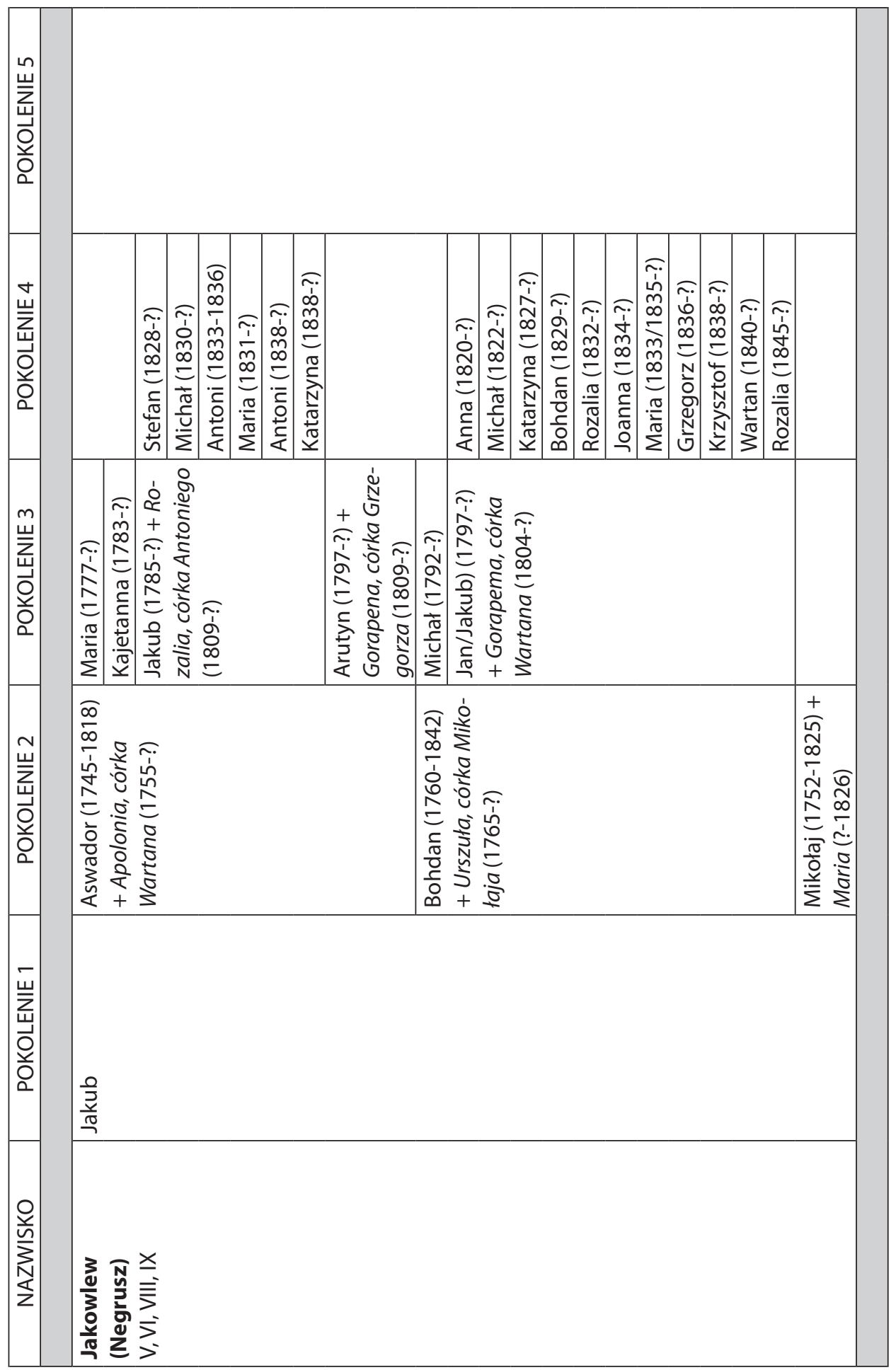




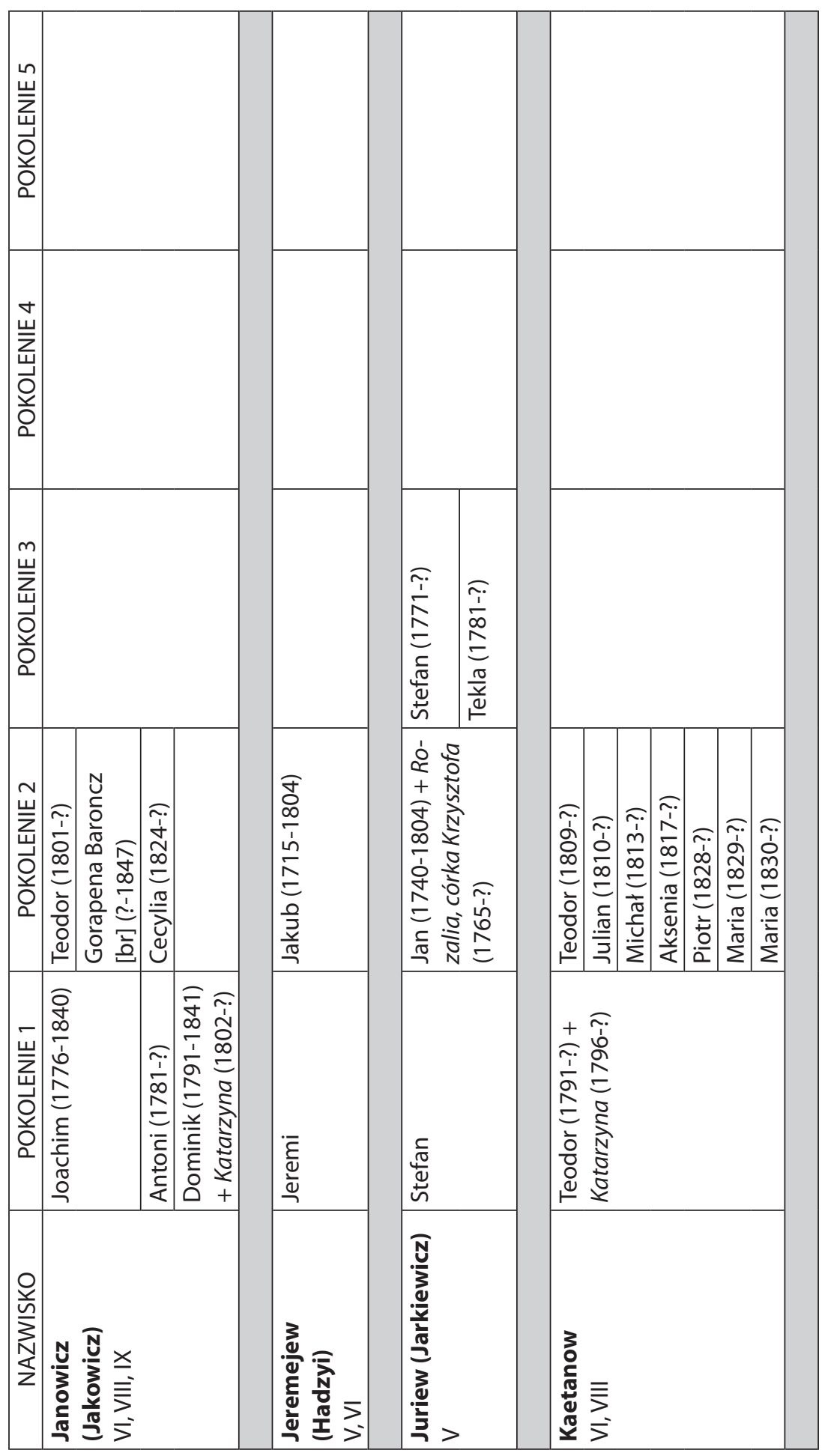




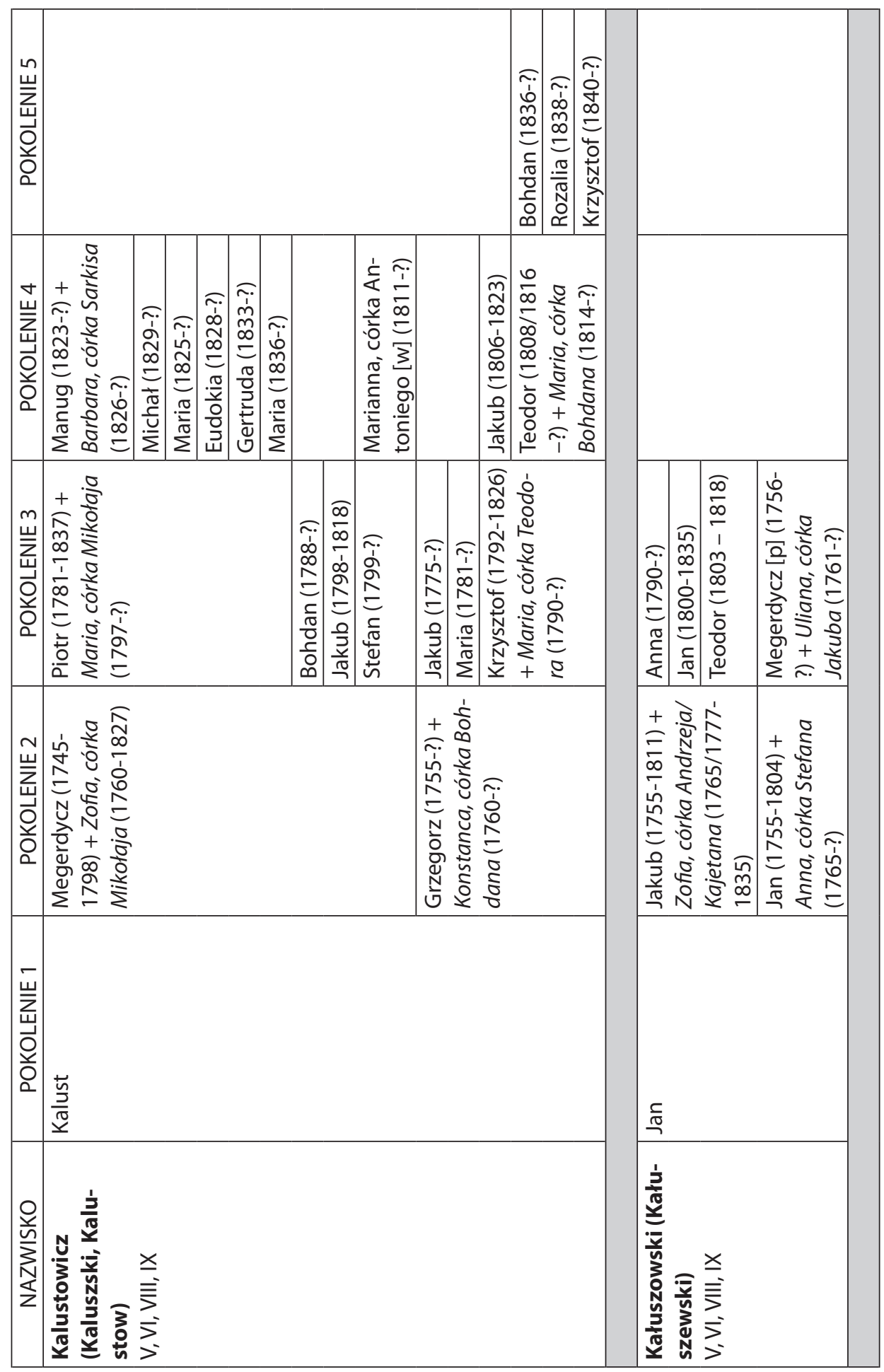




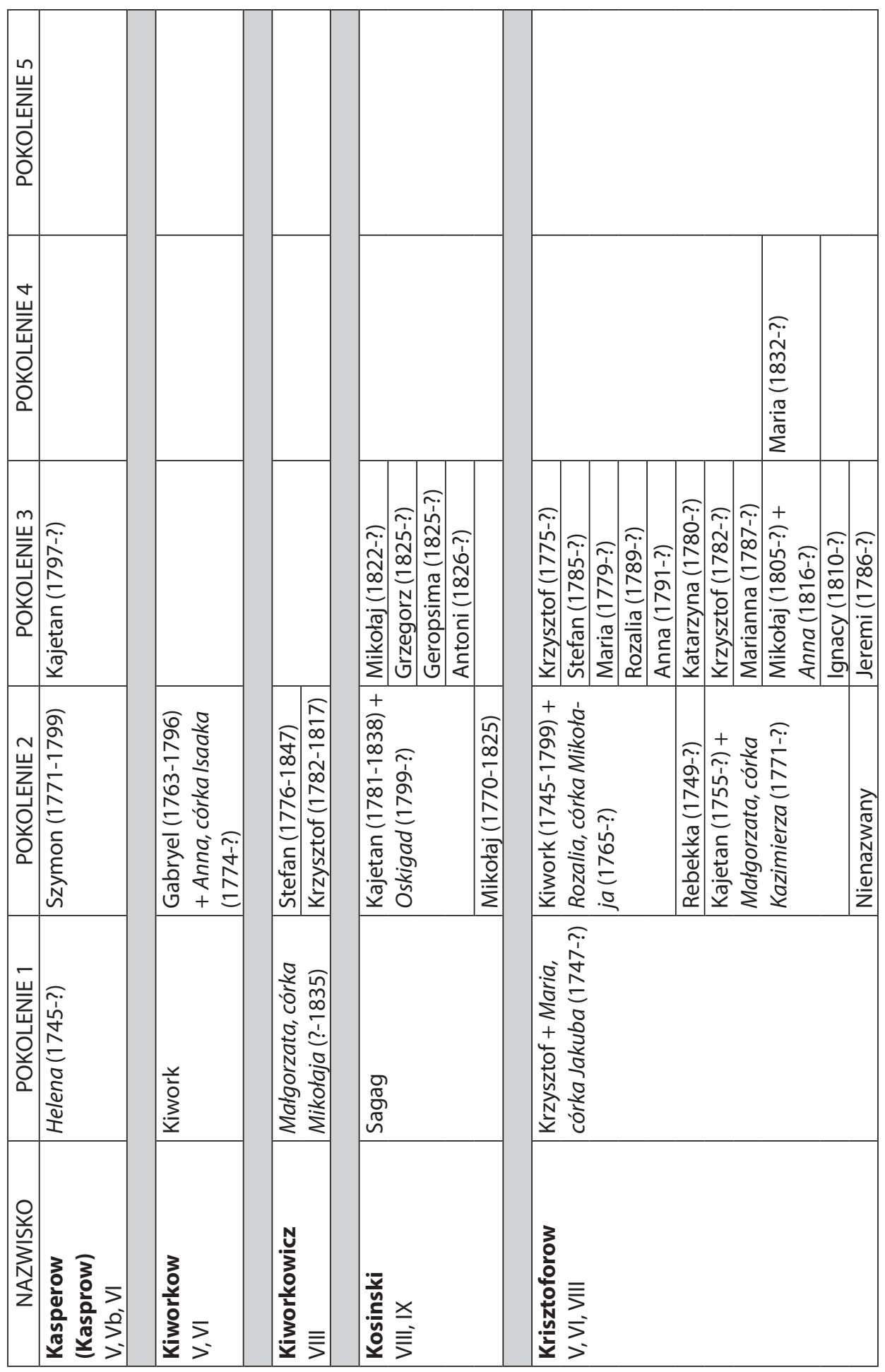




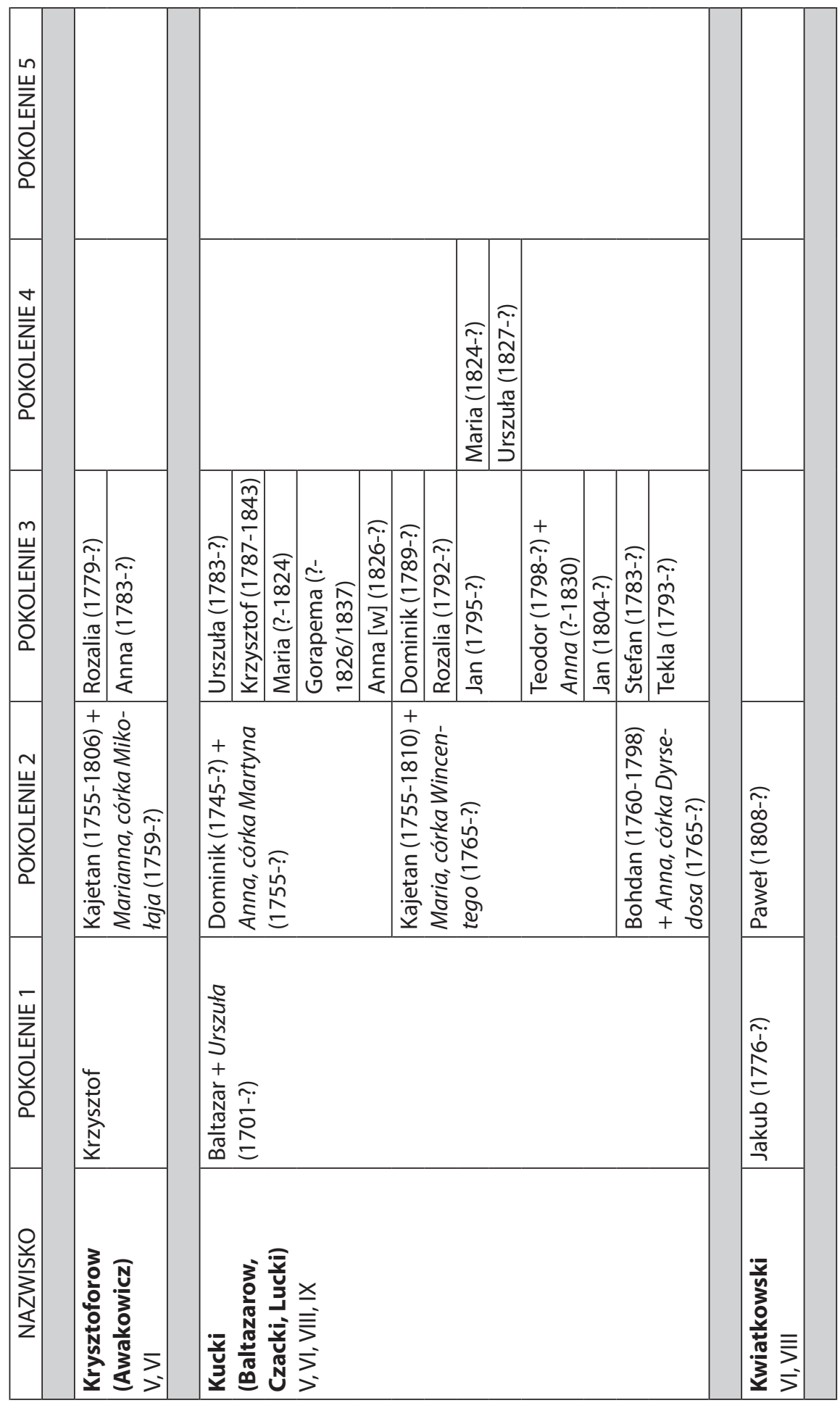




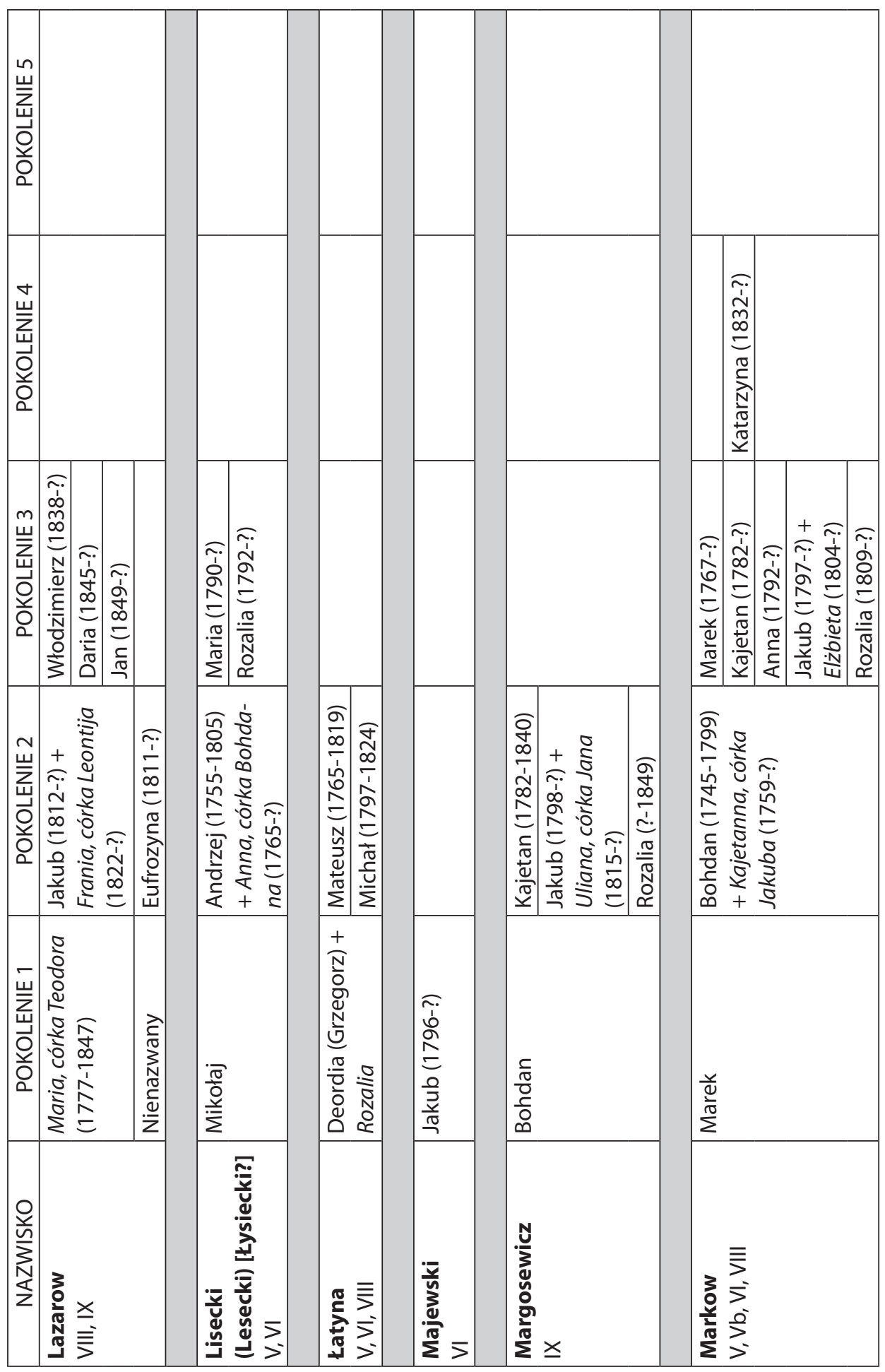




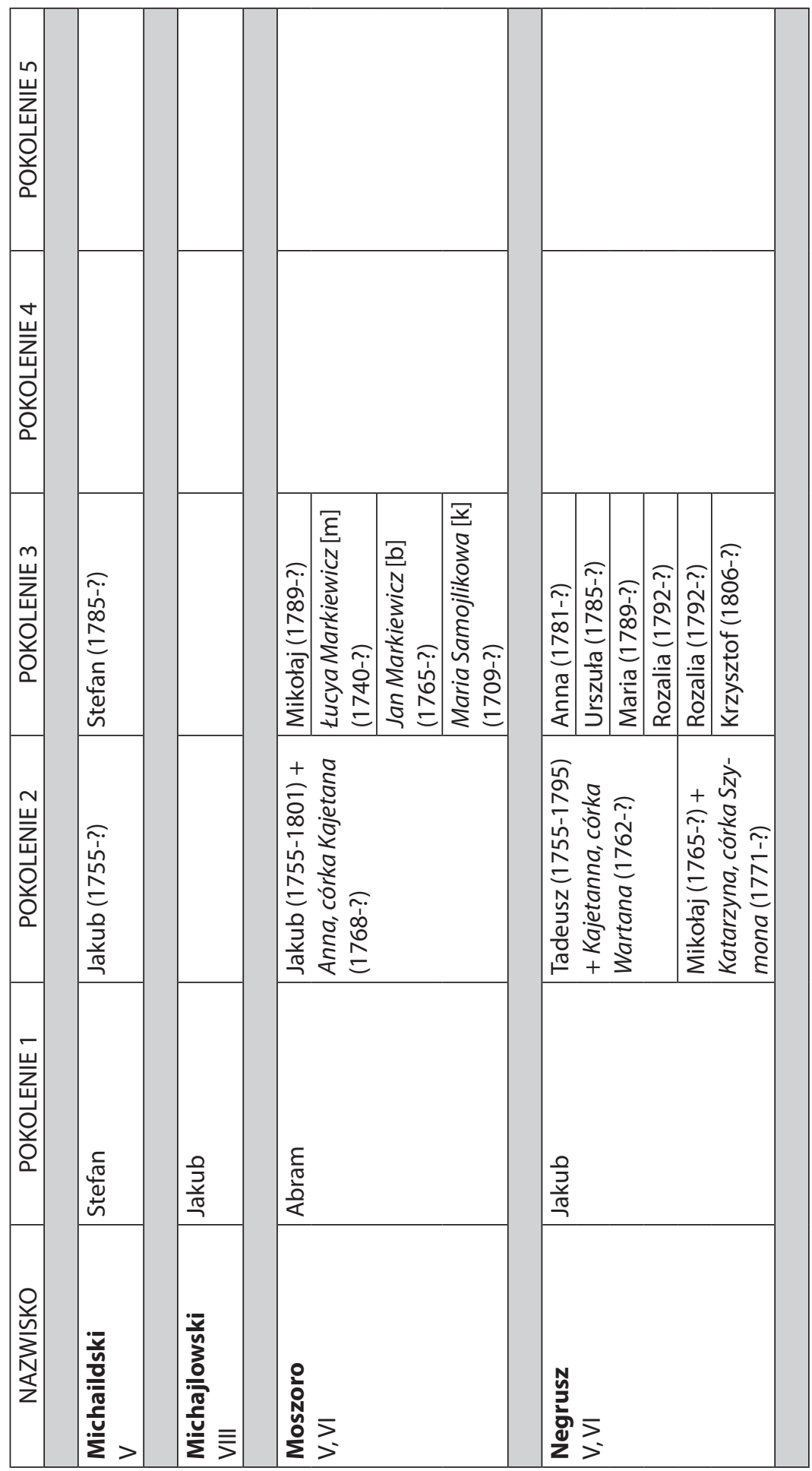




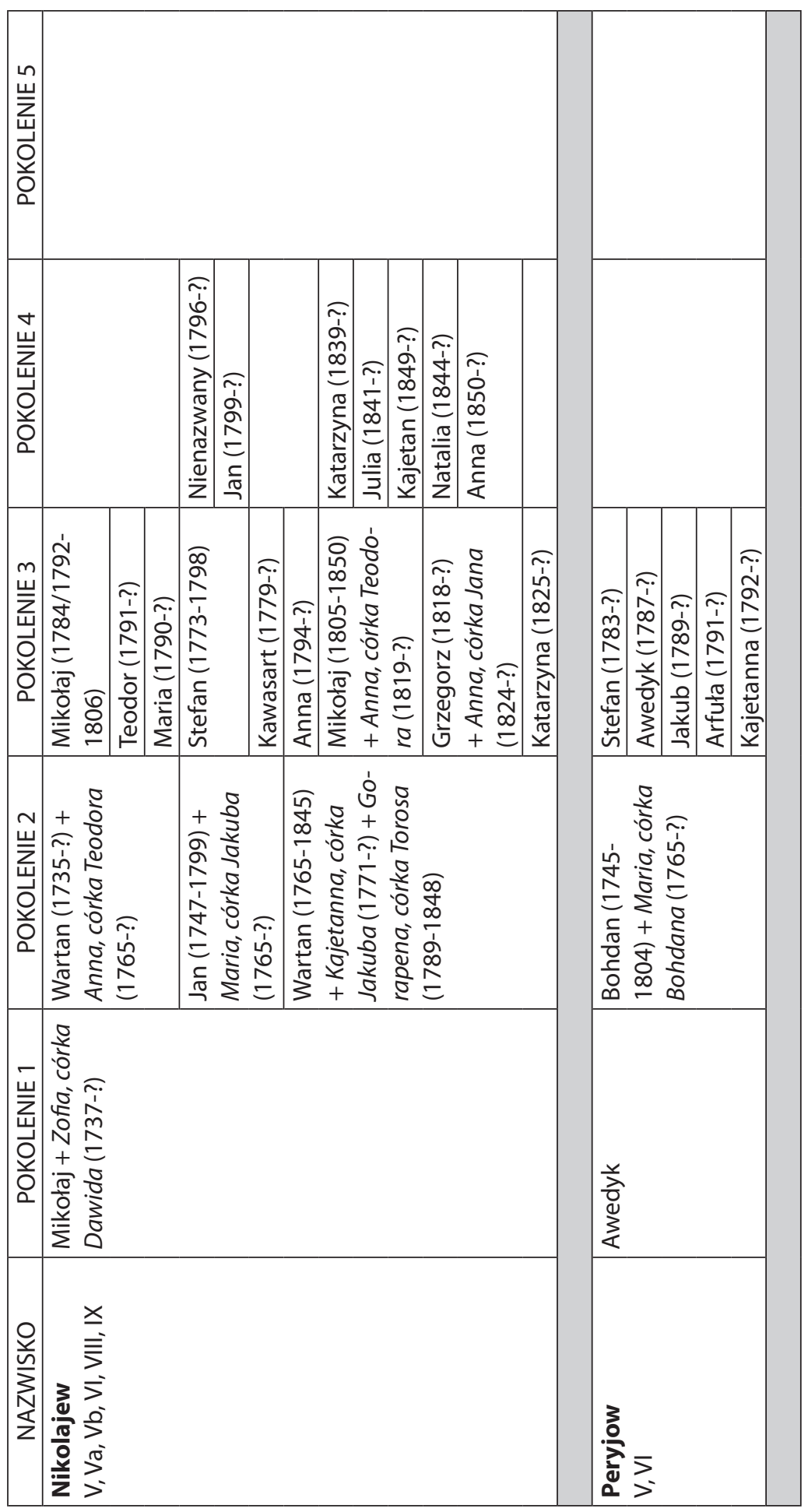




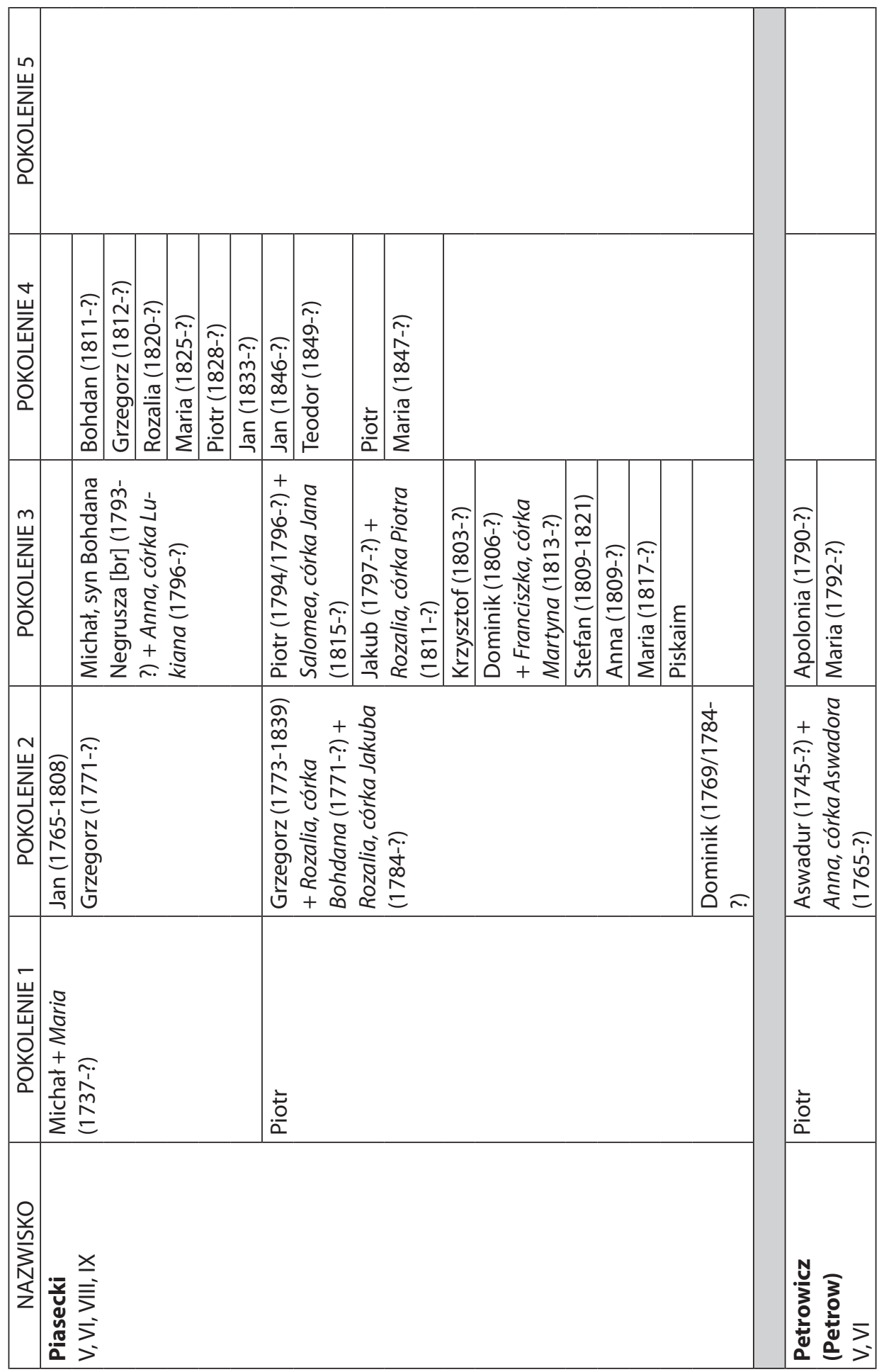




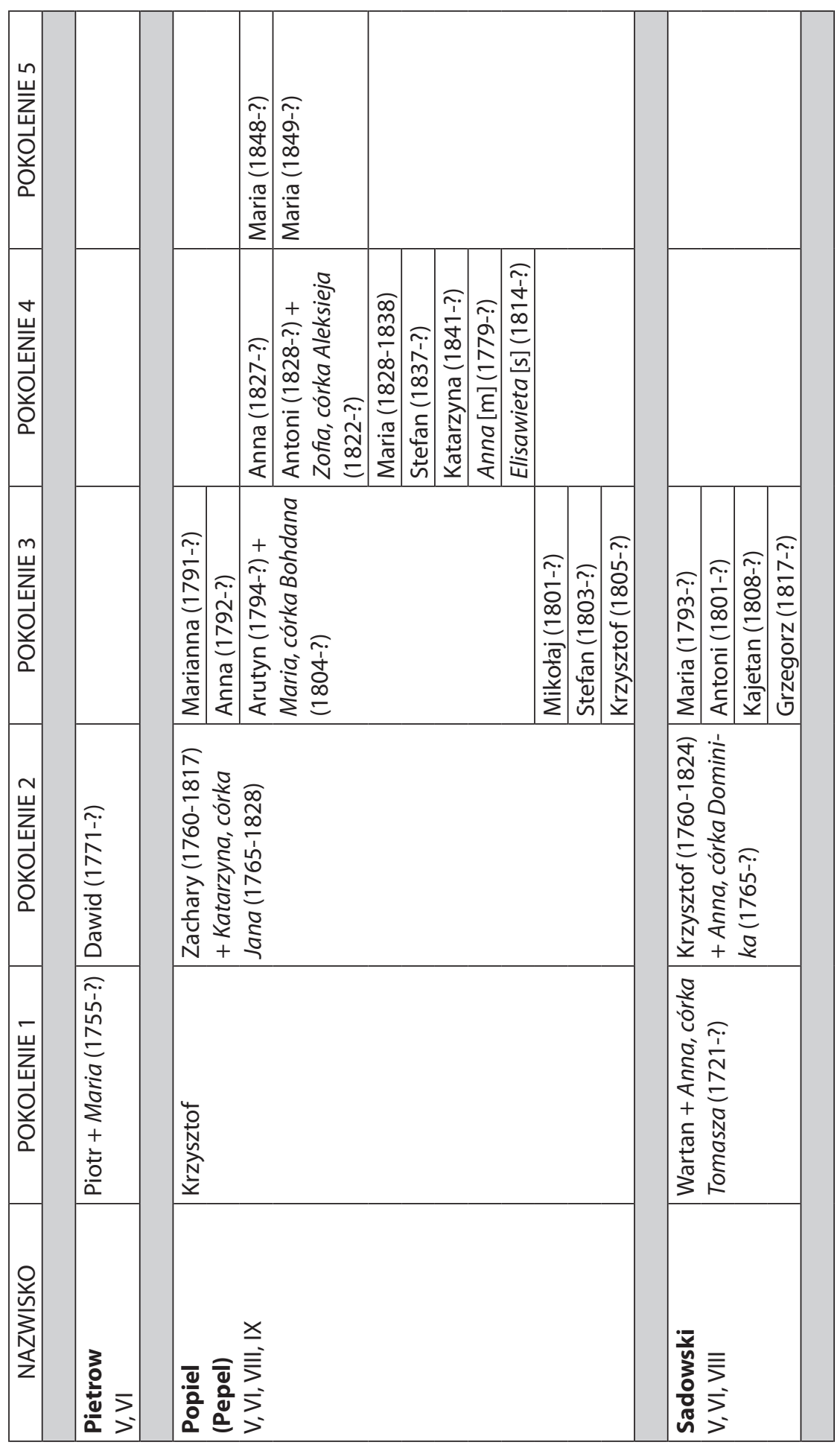




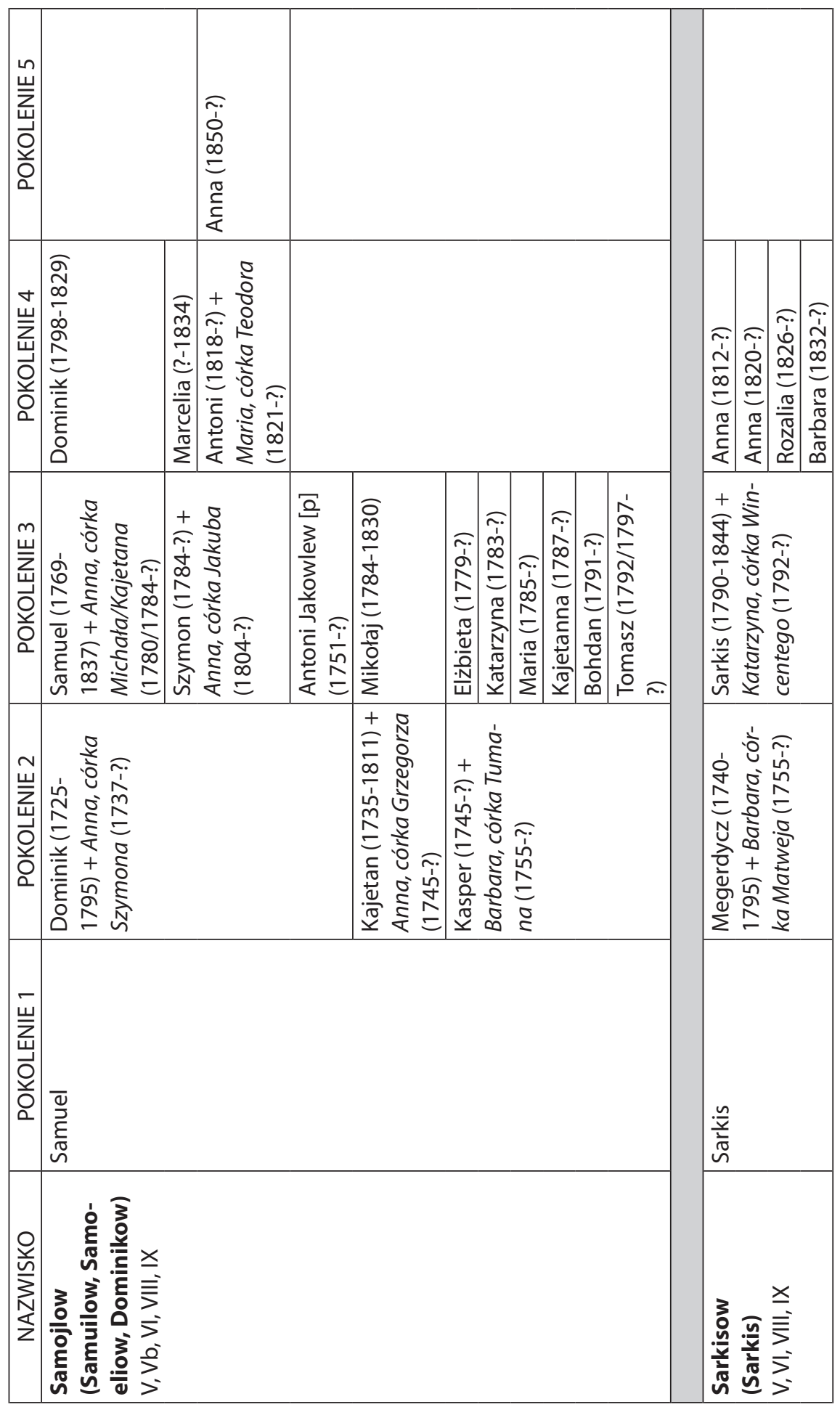




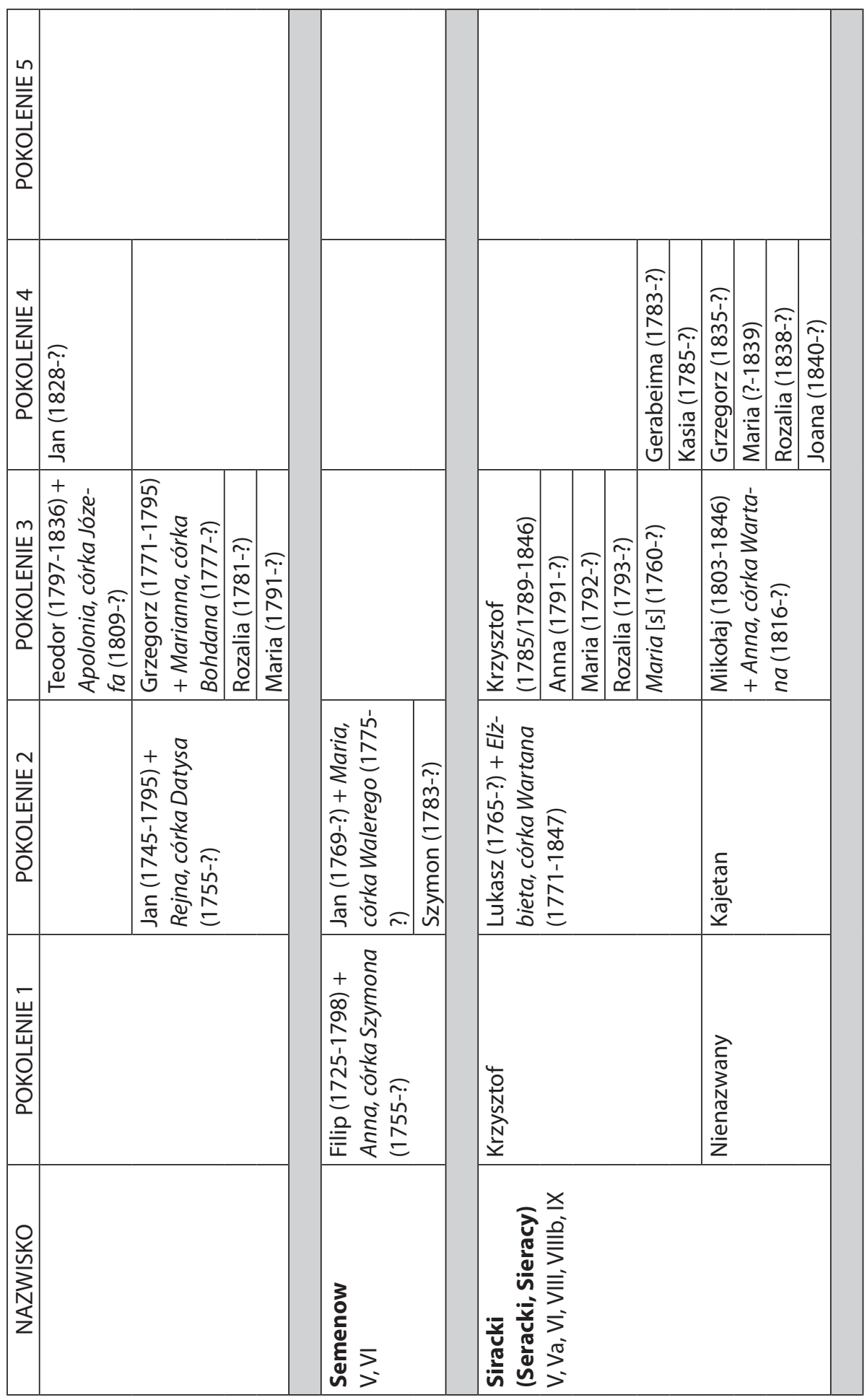




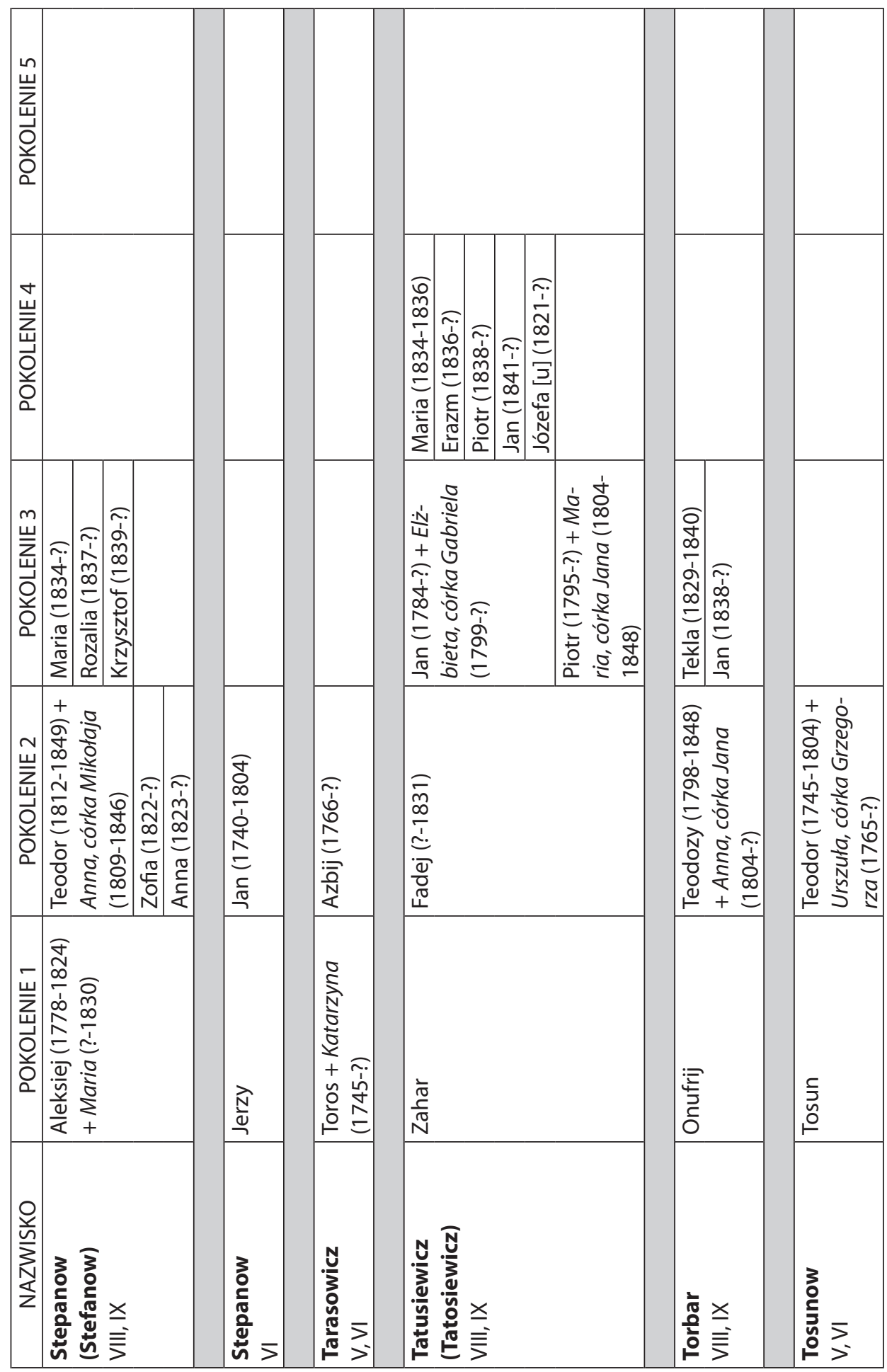




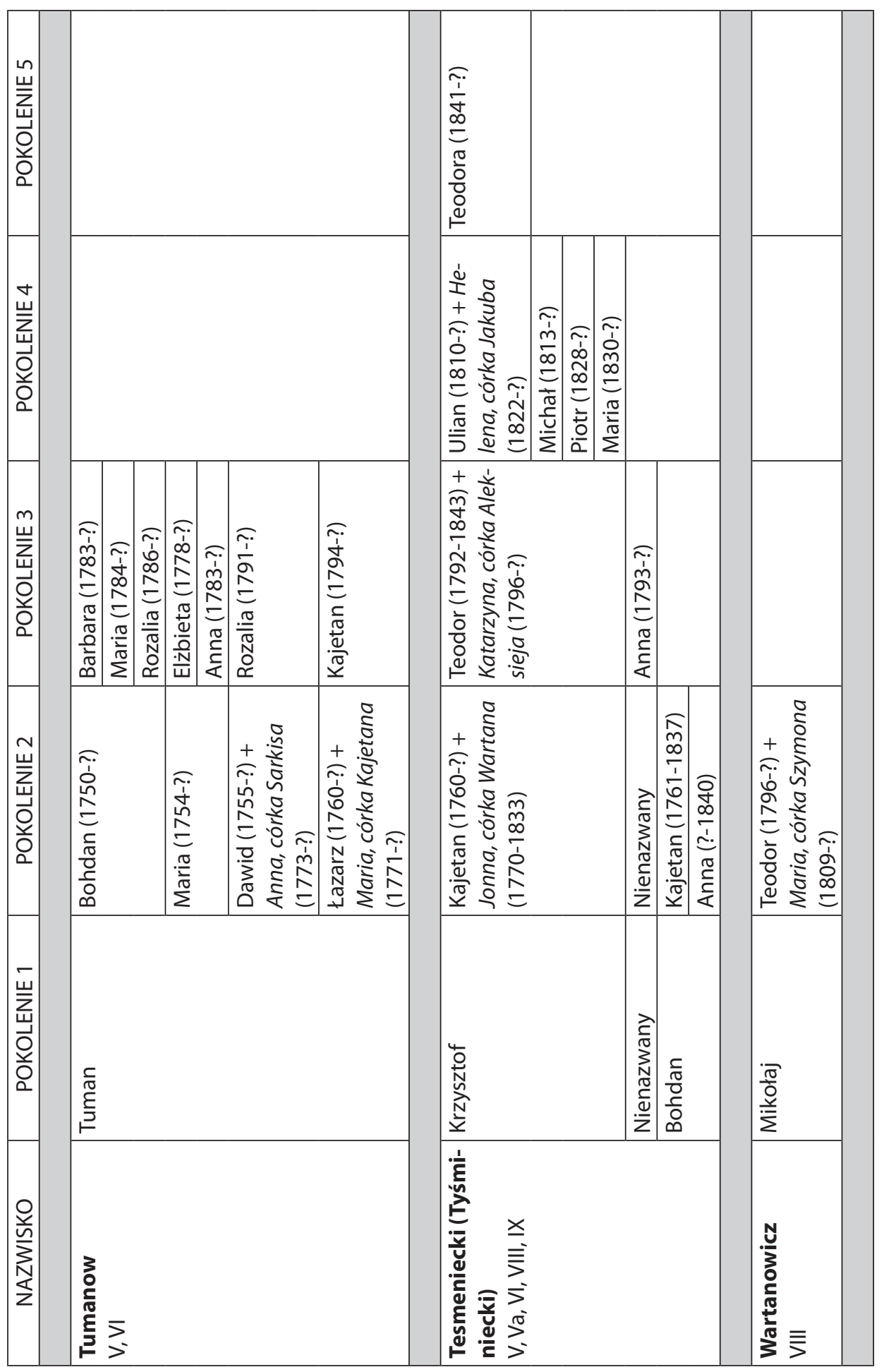




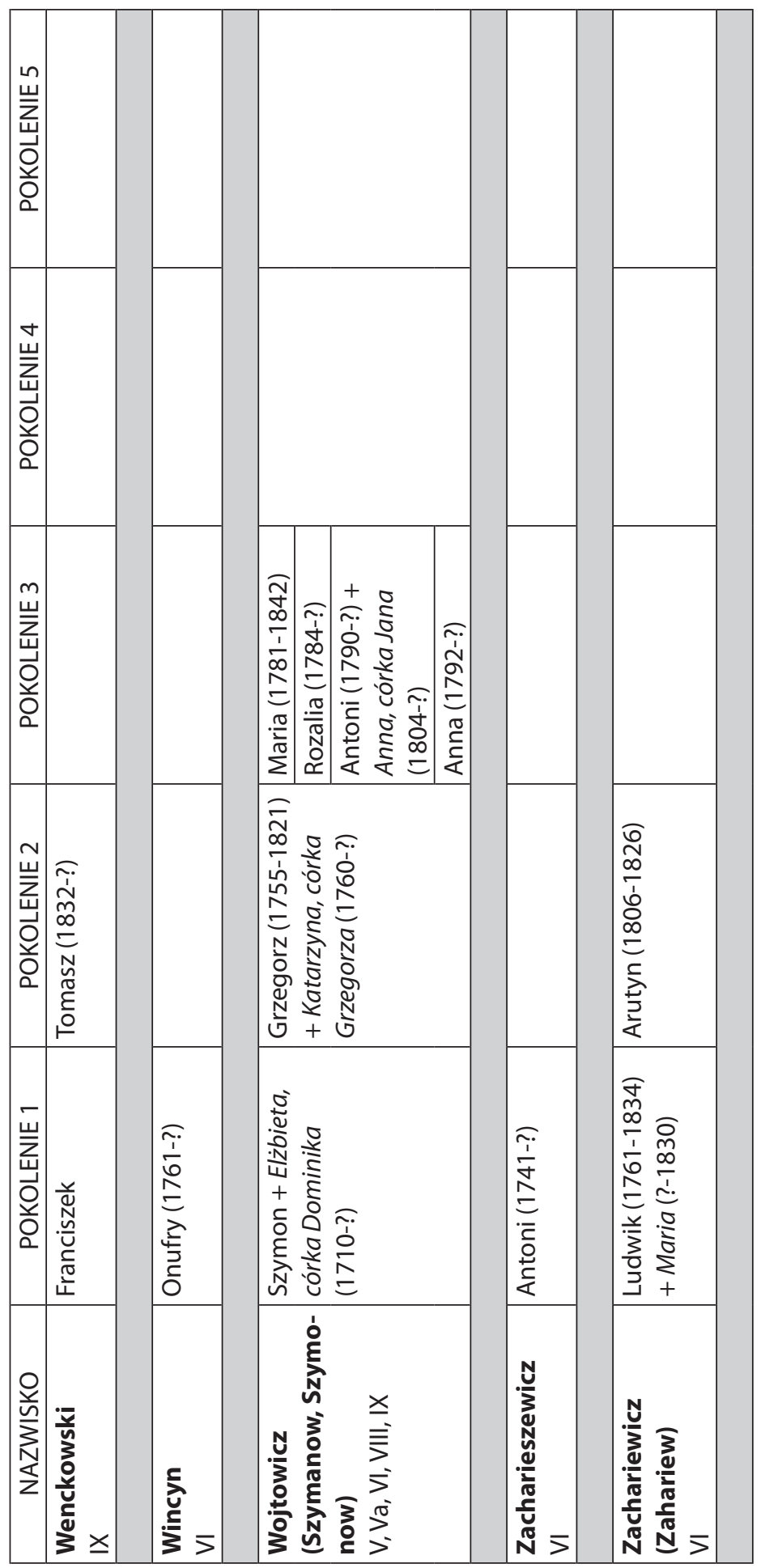




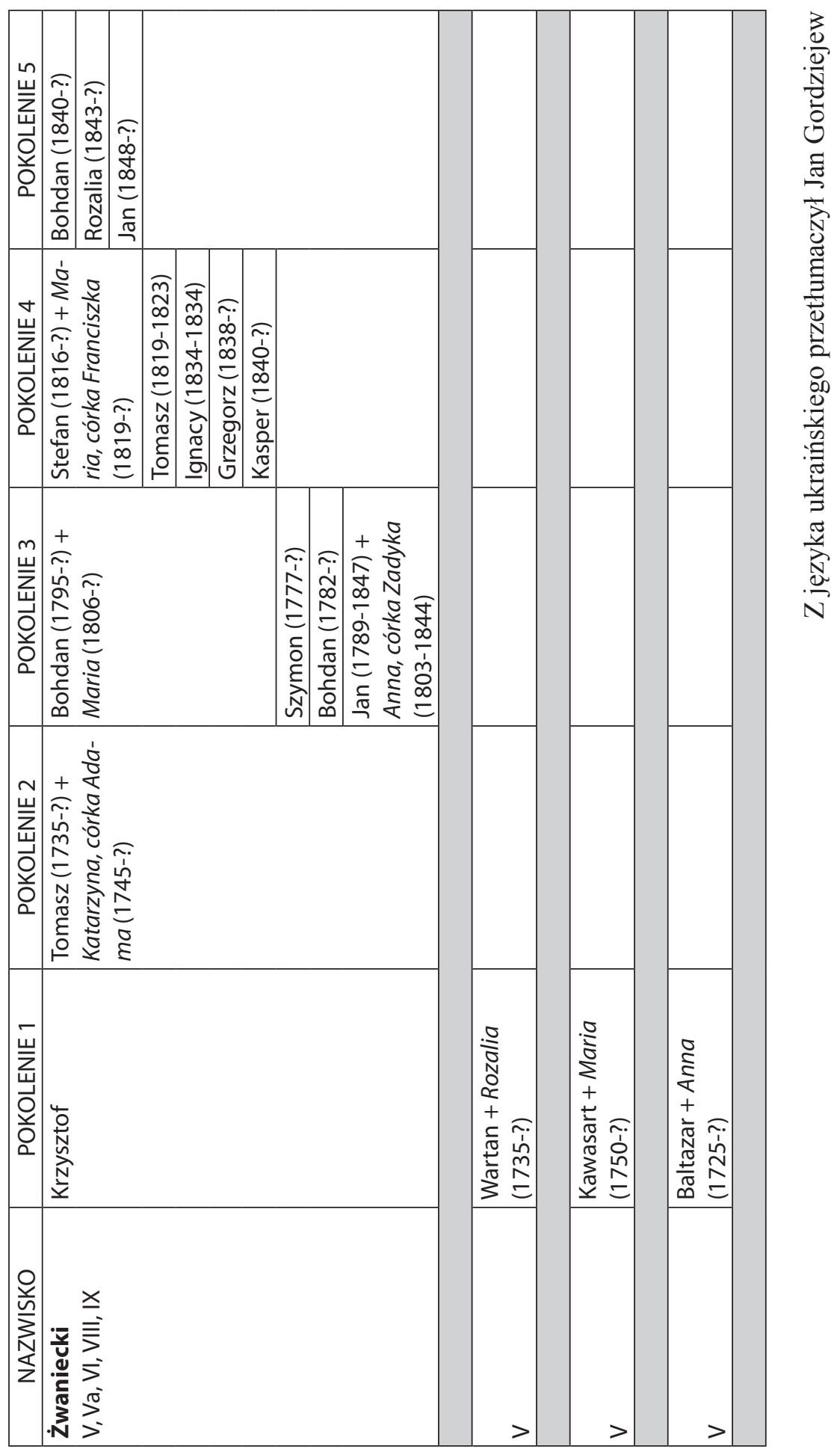


Aneks

Dokument 1. Inwentarz prywatnego miasta Mohylowa Podolskiego z 1772 roku (fragment)

5. Dalszy inwentarz danin in et $\mathrm{p}[\mathrm{ro}] 1772$ Anno

\begin{tabular}{|c|c|c|c|}
\hline Numer[us] & Osiadłość & Czynszu & \\
\hline ludzi & Ormian & $\mathrm{Zł} \mathrm{Gr}$ & \\
\hline 1. & Aswadu[r] Czaykowski & 4 & \\
\hline 2. & Eliasz Stefanowicz Woyt Ormian & 12 & \\
\hline 3. & Dominik Manukiewicz & 18 & \\
\hline 4. & Kaietan , & 18 & \\
\hline 5. & Jakub , & 18 & \\
\hline 6. & Toros Krzmicielowicz & 18 & \\
\hline 7. & Wartan , & 16 & \\
\hline 8. & Isaak , & 3 & \\
\hline 9. & Szymonowa Wdowa & 4 & \\
\hline 10. & Stambulczyka Wdowa & 2 & \\
\hline 11. & Marya Wołoszka Wdowa & 2 & \\
\hline 12. & Nastasijka Wdowa & 5 & \\
\hline 13. & Babyi Żołarz & 5 & \\
\hline 14. & Hadzyi Dawid & 8 & \\
\hline 15. & Magerdycz Kupiec & 5 & \\
\hline 16. & Alexander f 5 Ze zgorzał & & Liber Pogorzelec \\
\hline 17. & Kasper Tabacznik f 5 Ze zgorzał & & Liber Pogorzelec \\
\hline 18. & Iwonica Muntianka Wdowa & 4 & \\
\hline 19. & Mikołaj Azbajowicz & 10 & \\
\hline 20. & Mikołaj Czaykowski & 12 & \\
\hline 21. & Wartan Horodenski & 4 & \\
\hline 22. & Kirkur Kalustowicz & 10 & \\
\hline 23. & Baltazar Kucki & 12 & \\
\hline 24. & Daniel Stambulski & 6 & \\
\hline 25. & Konstanty Tabacznik & 4 & \\
\hline 26. & Girogos , & 6 & \\
\hline 27. & Toson , & 6 & \\
\hline 28. & Magerdycz Serkiesowicz & 4 & \\
\hline 29. & Toros Tabacharnik & 10 & \\
\hline 30. & Chaczyk Czaykowski & 5 & \\
\hline 31. & Nowasan Krawiec & 6 & \\
\hline 32. & Owanes Czaykowski & 5 & \\
\hline
\end{tabular}




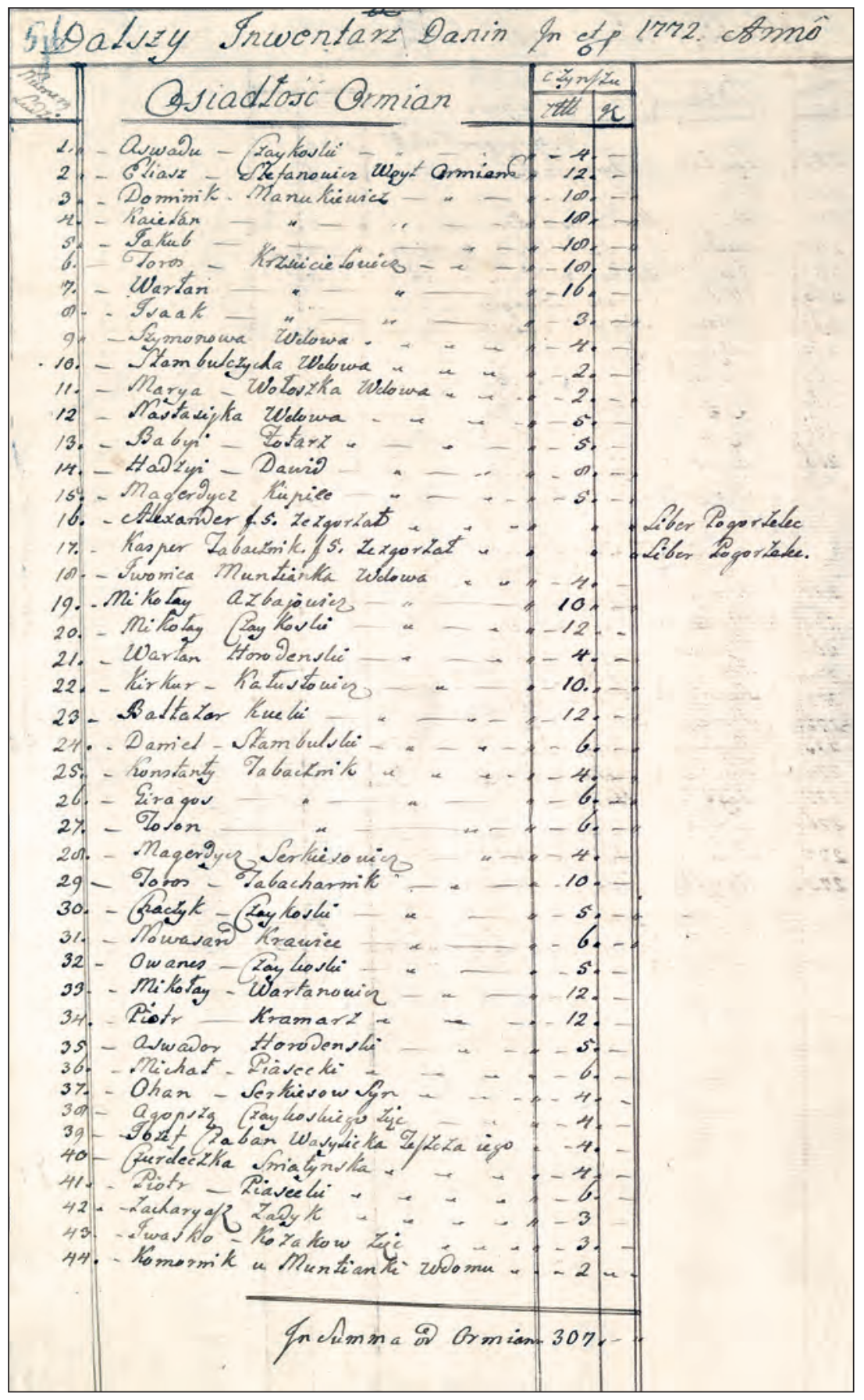

1. Fragment inwentarza z 1772 roku z wykazem głów rodzin ormiańskich Mohylowa Podolskiego, Центральний державний історичний архів України (Kijów): ф. 49, оп. 1, спр. 1855 , арк. 5зв. 


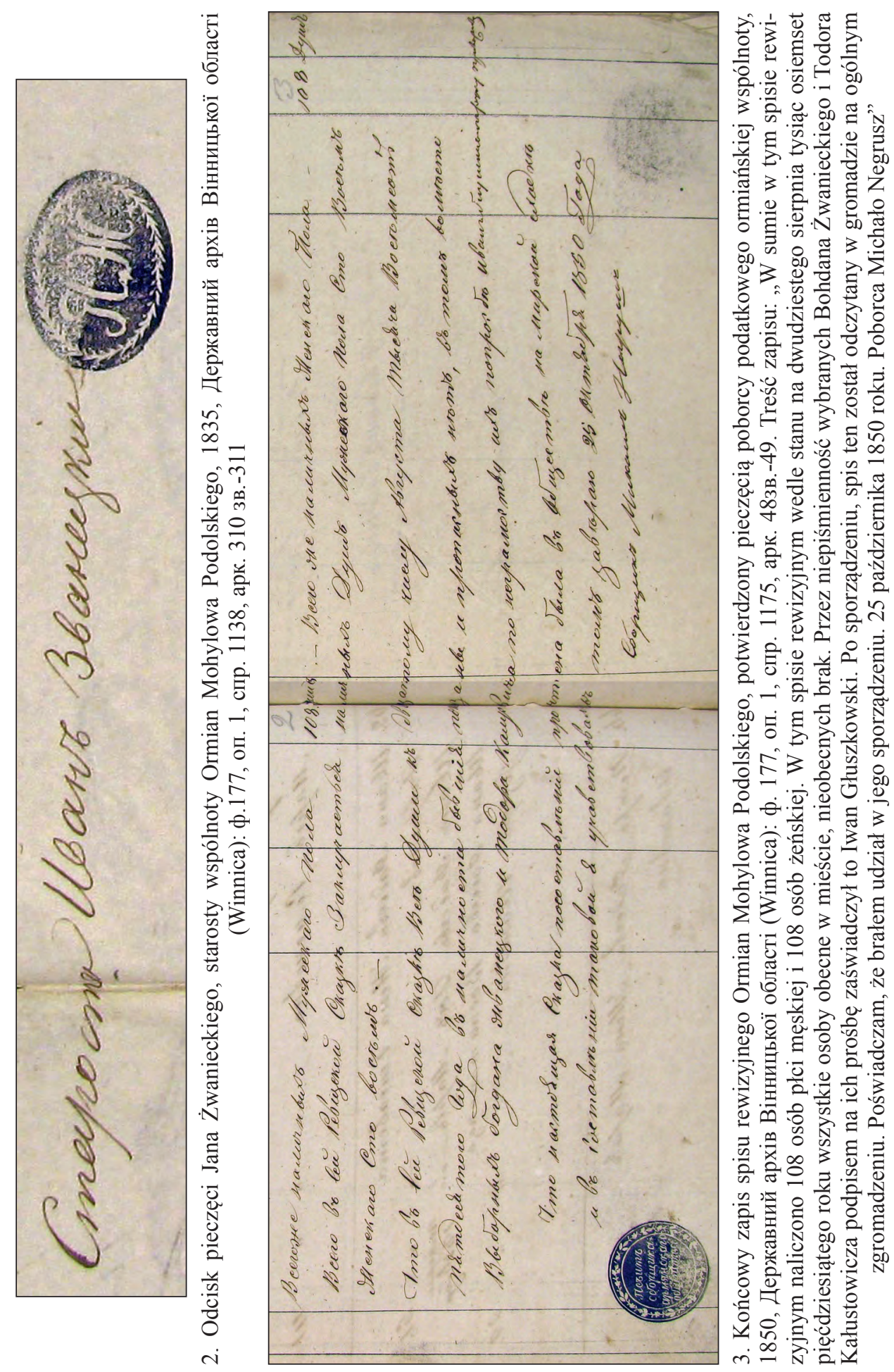


33.

Mikołaj Wartanowicz

12

34.

Piotr Kramarz

12

35.

Aswador Horodenski

5

36.

Michał Piasecki

6

37.

Ohan Serkiesow Syn

4

38.

Agopsza Czaykowskiego Zięć

4

39.

Jozef Czaban Wasylicka Teszcza iego

40.

Czurdeczka Sniatynska

\section{4}

4

6

Piotr Piasecki

3

42.

Zacharyasz Zadyk

$\begin{array}{lll}\text { 43. } & \text { Iwasko Kozakow Zięć } & 2 \\ \text { 44. } & \text { Komornik u Muntianki W domu } & 2\end{array}$

In Summa od Ormian

(ЦДІАУ: ф. 49, оп. 1, спр. 1855, арк. 5зв)

Dokument 2. Informacja wicegubernatora podolskiego w sprawie Ormian Mohylowa nad Dniestrem z 1869 roku ${ }^{40}$

5820

М.В.Д.

ПОДОЛЬСКАГО ГУБЕРНАТОРА

ПО КАНЦЕЛЯРИИ ГУБЕРНСКАГО УПРАВЛЕНИЯ

Отделение 1

Стол 2 й

№ 10084

15 ноября 1869 года

Каменец Подольский

27 НОЯ 1869

Господину Киевскому, Подольскому и Волынскому Генерал Губернатору

К исполнению предложения Вашего Сиятельства от 18 Сентября сего года за №4647, 27 Сентября было предписано Могилевскому Уездному Исправнику доставить надлежащия сведения к объяснению положения Могилевских Армян. Вследствие чего названный Исправник рапортом от

${ }^{40}$ Dokument zawiera fragmentaryczne wiadomości statystyczne dotyczące Ormian mohylowskich za lata 1858-1869, a oprócz tego uzupełnia treść dokumentów opublikowanych przez Wardgesa Mikaeliana. Dokumenty owe dotyczą przywrócenia w roku 1871 obowiązkowego poboru rekrutów spośród ormiańskich mieszkańców Mohylowa Podolskiego (В. Микаелян, Четыре документа, s. 101-105). 
13 Октября донес, что в Могилеве состояло в 1824 году причисленных Подольскою Казенною Палатою Армян, занимающихся выделкою сафьяна и саловарением и пользующихся Высочайше дарованною им льготою от рекрутской повинности 110 мужеска пола душ, за происшедшего же с того времени между этим обществом, до составления 10й народной переписи, убылью и прибылью по ревизским сказкам сей последней 10й переписи, записано 101 душа; с тех пор по настоящее время из них умерло 14, родилось 14, и теперь состоит на лице 109 душ; в том числе коренных Армян 101 и вновь причисленных Казенною палатою 8 душ мужескаго пола их бывшей польской шляхты; и что сказанные Армяне по настоящее время составляют отдельное общество от Могилевских мещан, отбывают повинности и платят подати бездоимочно в казну. Как же в прописанно донесении не заключалось сведений, выполняют ли Могилевские Армяне с платежем податей другие повинности, лежащие на Могилевском мещанском обществе, как наприм. подводную, постойную и проч., то 24 Октября предписано было Могилевскому Исправнику немедленно доставить означенныя сведения; ныне названный Исправник доносит, что армянское общество подводную, постойную и дорожную повинности, а также налог с недвижимых имуществ, земский и квартирный сбор, отбывают аккуратно.

Представляя о выше изложенном Вашему Сиятельству, с возвращением присланных при предложениях от 18 Сентября и 22 Октября за №4647 и 5403 приложений, имею честь доложить, что освобождением в 1824 году поселившихся в Могилеве на Днестре Армян от рекрутской повинности, натуральной и денежной, Правительство имело ввиду способствовать развитию в Подольском крае фабричнаго и промысловаго дела, так как Армяне эти занимались преимущественно выделкою сафьянных кож и саловарением. При этом было выражено, что льгота дается им, как иностранным переселенцам. Но цель Правительства не была достигнута, ибо Могилевские Армяне не только не создали из тогдашней своей специальности ощутительной и полезной для края промышености, которая могла бы заметно влиять на его благосостояние и не внесли в нее усовершенствованной техники, но напротив с течением времени, утратили эту специальность и в большинстве слились, по роду своих занятий, с общею массою мелких городских промышленников и торговцев. Таким образом, дальнейшее продление предоставленной им привиллегии не имеет ныне достаточного основания, тем более, что в позднейшем законодательстве Правительство отказалось уже от всякой идеи поддерживать промышленность искуственно, а тем более посредством привиллегий, клонящихся в ущерб общим Государственным пользам, каковою представляется освобождение Могилевских Армян от рекрутской повинности. Наконец Могилевских Армян, как подчиненных с столь давнего времени общим законам Империи, нельзя считать в настоящее время 
и иностранными переселенцами, причем присовокупляю, что руководствуясь этими соображениями и принимая во внимание, что изниченная льгота в отношении Могилевских Армян имела во всяком случае значение временной меры и что в настоящее время, вследствие последовавших изменений в способе отбывания рекрутской повинности, значительно облегчило исполнение ея наймом, я полагал бы вполне справедливым привлечь к отбыванию рекрутской повинности на общем основании и Могилевских Армян.

И. д. Губернатора Вицее Губернатор [podpis]

За Вице Губернатора Стариий Советник [podpis]

Столоначальник [podpis]

(ЩДІАУ: ф. 442, оп. 1, спр. 184, арк. 8-9зв.)

Tłumaczenie na język polski (wykonał Stanisław Ulaszek):

5820

$\mathrm{M}$ [inisterstwo] S[praw] W[ewnętrznych]

[Od] GUBERNATORA PODOLSKIEGO

Przez KANCELARIĘ ZARZĄDU GUBERNIALNEGO

Oddział 1

Biuro 2

Nr 10084

15 listopada 1869 roku

Kamieniec Podolski

27 list[opada] 1869

Do Pana Gubernatora Generalnego Kijowskiego, Podolskiego i Wołyńskiego

Zgodnie z poleceniem Waszej Ekscelencji, w dniu 18 września bieżącego roku (pismo nr 4647 z dnia 27 września) zobowiązano Naczelnika Powiatu Mohylowskiego do przedstawienia informacji o aktualnej sytuacji Ormian mohylowskich. [W wyniku tegoż rzeczony] Naczelnik Powiatu w raporcie z dnia 13 października poinformował, że w roku 1824 w Mohylowie - według danych Państwowej Izby Podolskiej - zamieszkiwało 110 Ormian płci męskiej trudniących się wyprawianiem safianu (ze skór zwierzęcych) i wytapianiem tłuszczu, którzy - na mocy przyznanego im łaskawie przez Najwyższą Władzę przywileju - byli zwolnieni z powszechnego obowiązku rekruckiego; podczas 10. spisu ludności, w którego trakcie odnotowywano zarówno liczbę narodzin, jak i zgonów, stwierdzono istnienie 101 żyjących dusz; od tamtego czasu do 
chwili obecnej zmarło 14 i narodziło się 14 osób, jest ich więc obecnie 109 dusz; w tym rdzennych Ormian 101, zaś 8 osób (płci męskiej), wciągniętych do rejestru ludności przez Państwową Izbę Podolską, wywodziło się z polskiej szlachty. Rzeczeni Ormianie do chwili obecnej stanowią odrębną grupę społeczną wśród mieszczan Mohylowa, płacą przy tym na rzecz państwa należne podatki w pełnym wymiarze oraz spełniają inne względem niego powinności. A ponieważ we wspomnianym raporcie nie było mowy o tym, czy mohylowscy Ormianie podobnie jak pozostali mieszczanie - wypełniają również inne powinności, np. podwodową, kwaterunkową itp., to 24 października polecono Naczelnikowi mohylowskiemu uzupełnić brakującą informację; obecnie rzeczony Naczelnik donosi, że ormiańska społeczność Mohylowa spełnia zarówno podwodową, jak i kwaterunkową powinność, a także regularnie i bez opóźnień płaci podatki od nieruchomości, gruntów oraz lokali.

Przedstawiając Waszej Ekscelencji powyższą informację i odsyłając przy tym załączniki do otrzymanych zarządzeń nr 4647 i nr 5403 z 18 września oraz 22 października, mam zaszczyt zameldować, że zwalniając w roku 1824 osiadłych w Mohylowie nad Dniestrem Ormian od obowiązku służby wojskowej, a także świadczeń naturalnych i pieniężnych, Rząd pragnął wspomóc i przyśpieszyć rozwój przemysłu i rzemiosła w Kraju Podolskim, jako że Ormianie trudnili się przeważnie wyrobem safianowych skór i wytapianiem tłuszczu. Przy tym wyrażono zastrzeżenie, iż wspomniany przywilej został im przyznany jako przesiedleńcom-obcokrajowcom. Rząd jednak nie osiągnął założonego celu, albowiem mohylowscy Ormianie nie tylko nie zainicjowali powstania w ramach swej specjalności potrzebnego przemysłu, który mógłby korzystnie wpłynąć na rozwój i ogólny wzrost dobrobytu kraju, nie udoskonalili też techniki wytwarzania swoich wyrobów, lecz przeciwnie $-\mathrm{z}$ upływem czasu zatracili swoje wcześniejsze umiejętności - i przeważająca ich liczba zasymilowała się z ludnością miasta, stając się drobnymi kupcami i rzemieślnikami, podobnie jak znaczna część mieszkańców Mohylowa. $Z$ tego względu dalsze przedłużanie terminu pozostawania w mocy przyznanego im przywileju nie wydaje się zasadne, tym bardziej, że w późniejszym ustawodawstwie Rząd oficjalnie wycofał się z popierania jakiejkolwiek idei sztucznego stymulowania rozwoju przemysłu, zwłaszcza zaś poprzez nadawanie przywilejów ze szkodą dla budżetu Państwa, co też z naszego punktu widzenia nastąpiło w rezultacie nadanego mohylowskim Ormianom przywileju zwalniającego ich od obowiązkowej służby wojskowej. Podsumowując, mohylowskich Ormian, od dawna będących obywatelami Rosji podlegających jego ustawodawstwu, nie należy obecnie uważać za przesiedlonych cudzoziemców; przy tym ośmielam się dodać, że przyznane niegdyś mohylowskim Ormianom ulgi nosiły jedynie doraźny charakter, toteż na skutek przejścia z obowiązkowego poboru rekrutów na wojskową służbę 
najemną, co znacznie usprawniło jej przebieg, proponowałbym, aby mohylowscy Ormianie również na ogólnie obowiązujących zasadach do niej wstępowali.

P[ełniący] o[bwiązki] Gubernatora Wicegubernator [podpis]

Za Wicegubernatora Starszy Radca [podpis]

Naczelnik Biura [podpis]

\section{Bibliografia}

\section{Źródła archiwalne}

[Centralnyj] Центральний державний історичний архів України, м.Київ: ф. 49, оп. 1, спр. 1855 ; ф. 442, оп. 48, спр. 184

[Derżawnyj] Державний архів Вінницької області (Winnica): ф. 177, оп. 1, спр. 810, 1099, 1138, 1175; ф. 475, оп. 1, спр. 14

\section{Opracowania}

[Grigorian W.] Григорян В., История армянских колоний Украины и Польши (армяне Подолии), Ереван 1980

[Mikaelian W.] Микаелян B., Четыре документа по истории могилевских армян, „Lpuptep huuupulquiluid qhunnıpjnı\&ikiph” [Biuletyn Nauk Społecznych], 1978, 9, s. 1

Pobóg-Górski W., Powiat mohylowski w Guberni Podolskiej. Opis geograficzno-historyczny wszystkich miast i miasteczek, wsi, przysiołków, futorów, słowem zaludnionych miejscowości w tym powiecie, z dodaniem odpowiednych dokumentów, Kraków 1902

Potapenko M., Ormianie Mohylowa Podolskiego w świetle materiałów V rewizji 1795 roku, „Lehahayer”, 6, 2019, s. 91-124, https://doi.org/10.12797/LH.06.2019.06.03

Stopka K., Zięba A. A., Ormiańska Polska, Warszawa 2018

Maksym Potapenko, Armenians in Mohylów Podolski (Mohyliv-Podilskyi) at the end of the 18th century and in the middle of the 19th century (on the basis of the statistical measurement of the people)

Abstract: The author presents the analysis of five statistical sources which document social and demographical character of the Armenian commune in Mohylów Podolski from the end of the 18th century to the middle of the 19th century. These sources include: inventory of the town form 1772 and the so-called revisions, conducted on the order of the Russian authorities in 1795, 1811, 1834 and 1850. As a result, it as possible to determine the names of at least 600 Mohylów Armenians from 70 families. Moreover, the thesis was confirmed that Armenians in this town constituted the distinct and privileged social group, which - as Vartan Grigoryan already believed - was declining, primarily because of the unfavourable economic situation after the incorporation of Podole into Russia.

Keywords: Armenians, Mohylów Podolski (Mohyliv-Podilskyi) 


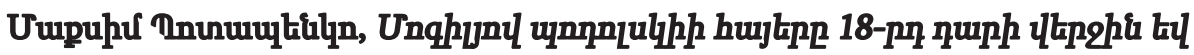

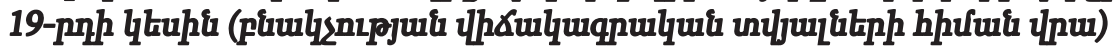

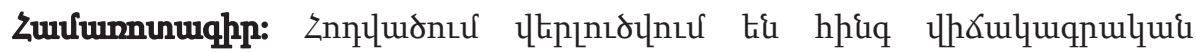

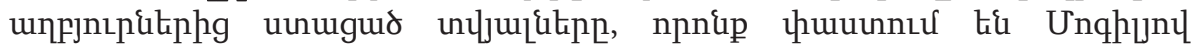

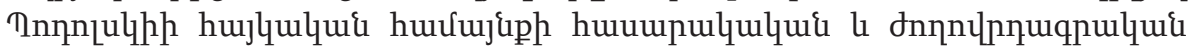

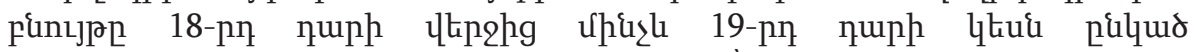

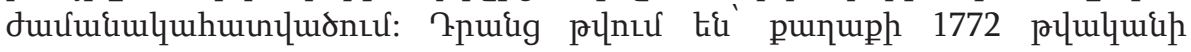

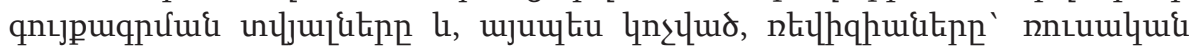

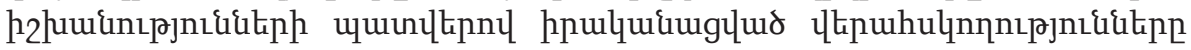

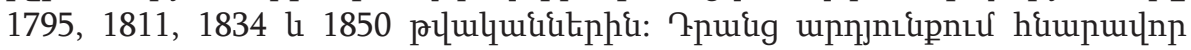

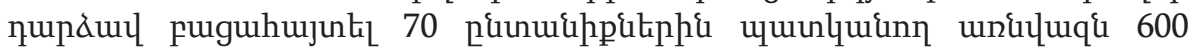

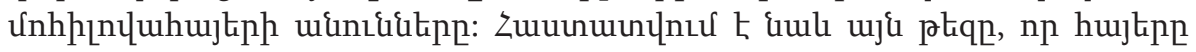

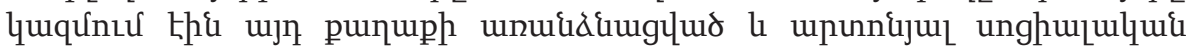

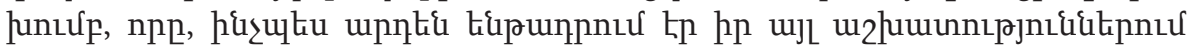

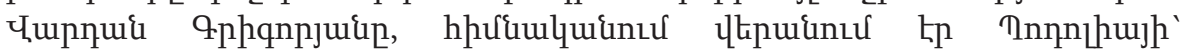

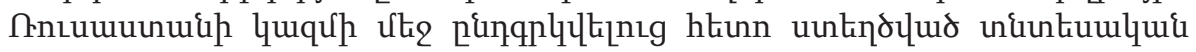

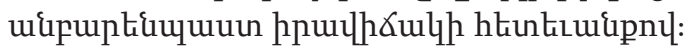

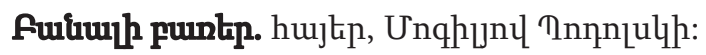

